\title{
Stanovanjske soseske v Katmanduju: glavne oblikovalske smernice
}

Stanovanjske soseske, ki sta jih v Katmanduju z različnimi tehnikami zgradila javni in zasebni sektor, zagotavljajo slabo urbano okolje ter ne rešujejo dovolj učinkovito socialnih in kulturnih potreb stanovalcev. Poleg tega ne prispevajo dovolj k oblikovanju občutka pripadnosti skupnosti in se slabo povezujejo $s$ preostalim grajenim okoljem, pri čemer ljudje na načrtno zgrajenih območjih ne občutijo pripadnosti kraju in se tako počutijo kot brezdomci. Čeprav je tradicionalna soseska v starem mestnem jedru nekoč imela številne značilnosti dobre stanovanjske soseske, danes hitro propada. Stanovalci omenjenih so- sesk se teh težav ne zavedajo preveč. Ker obstoječi pravni in institucionalni okviri niso ustrezni in učinkoviti, ne morejo rešiti opisanih težav. Tako je za prihodnji razvoj stanovanjskih sosesk treba razviti oblikovalske smernice, ki se morajo izvajati strogo, ob tem pa je treba okrepiti tudi družbeno-kulturne dejavnosti, kot je navezovanje stikov.

Ključne besede: stanovanjska soseska, družbeno-kulturno okolje, skupnost, Katmandu, oblikovalske smernice 


\section{Uvod}

Stanovanjske soseske so najpomembnejša prvina načrtovanja mest. Ker je stanovanjska raba najpogostejša vrsta rabe zemljišč v mestih, te soseske določajo rast mest, nudijo prostor za druženje in rekreacijo, povečujejo gospodarsko vzdržnost ter izražajo ljudsko arhitekturo in dnevne dejavnosti prebivalcev. Te raznolike vloge pa so bile $\mathrm{v}$ hitrem procesu urbanizacije in širjenja naselij v glavnem mestu Nepala močno spregledane, saj je povpraševanje po stanovanjih, infrastrukturi in javnih dobrinah vse večje. Načrtna gradnja na podlagi treh različnih tehnik gradnje (vladni programi za prostor in storitve, usmerjena gradnja in skupno urejanje zemljišč) ni mogla zadovoljiti vse večjih potreb po zemljiščih in stanovanjih. Določbe nacionalnega gradbenega zakonika in zakona o lastništvu skupnih stanovanj 2054 iz leta 1997 (ang. Ownership of joint housing act, 2054 (1997), uradni list Republike Nepal z dne 15. aprila 2003) so se slabo izvajale. Tudi za novoustanovljene organizacije - kot so odbor doline Katmanduja za mestni razvoj (pred kratkim preimenovan v razvojni urad doline Katmanduja), ministrstvo za stanovanja in prostorsko načrtovanje, ustanovljeno leta 1988 (zdajšnje ministrstvo za prostorsko načrtovanje in delo), ter pred kratkim ustanovljeno ministrstvo za mestni razvoj - se je izkazalo, da niso zadostne in učinkovite. Preobrazba tradicionalne stanovanjske soseske v starem mestnem jedru in oblikovanje novih stanovanjskih območij, ki načrtno ali nenačrtno nastajajo na obrobju mesta, do zdaj še nista bila kritično analizirana. Na podlagi opisanega avtor kritično preučuje in med seboj primerja različne stanovanjske soseske v Katmanduju. Najprej je predstavljen pregled obsežne literature o stanovanjskih soseskah, čemur sledi oblikovanje analitičnega okvira, ki avtorju služi kot podlaga za kvantitativno in kvalitativno primerjavo različnih stanovanjskih sosesk. Nato avtor določi številne slabosti njihovega načrtovanja in gradnje. Članek se konča s sklepom, v katerem avtor predlaga tudi nekatere pomembne oblikovalske smernice za gradnjo ustreznih stanovanjskih naselij v prihodnosti.

\section{Teorije o stanovanjskih soseskah}

Zgodovinsko gledano so bile stanovanjske soseske dragocene enote človeških naselij, pa naj je šlo za kvadratno zasnovo grških in rimskih mest, stihijska srednjeveška mesta ali radialne in krožne načrte evropskih mest v obdobju renesanse (Colquhoun in Fauset, 1991). Za obdobje pred 19. stoletjem so bila značilna gosto pozidana stanovanjska območja $\mathrm{z}$ javnimi prostori (trgi) in s stanovanjskimi enotami, ki so ustvarjale vzorec izmenjujočih se praznih in pozidanih delov. $\mathrm{Z}$ industrijsko revolucijo se je pospešila množična gradnja stanovanj $s$ premajhno uporabno površino, slabo infrastrukturo, slabimi sanitarijami, z malo svetlobe, s slabim prezračevanjem in z malo skupnimi prostori oziroma brez njih, saj je bilo treba zadostiti stanovanjskim potrebam velikega pritoka delavcev v mestna središča. Po drugi strani je industrijska revolucija povzročila nenačrtno širjenje nizkih in redko pozidanih novogradenj, ki so bile večinoma namenjene bogateǰsim prebivalcem predmestij. Kot odziv na slabe bivalne razmere delavcev v množičnih stanovanjih sta Ebenezer Howard (1850-1928) s konceptom vrtnega mesta v Angliji in William E. Drummond s konceptom enote soseske ${ }^{11]}$ (ang. neighbourhood unit) v ZDA predlagala novo stanovanjsko okolje z novo mestno družbo, kar ni vplivalo samo na sodobno načrtovanje mest, ampak do neke mere tudi vzdrževalo družbeno ekonomijo. V naslednjih letih je veliko britanskih in ameriških mest prevzelo to načrtovalsko filozofijo. Pred drugo svetovno vojno so gradbeniki običajno preprosto kupili parcele na že oblikovanih mestnih ulicah, zgradili več hiš naenkrat in jih povezali s socialnim in poslovnim tkivom mesta. Po vojni so investitorji ${ }^{[2]}$, ki so zamenjali gradbenike, začeli oblikovati načrte za pozidavo obsežnih območij neobdelane zemlje, na katerih so v kratkem času zgradili ogromno število identičnih stanovanjskih enot, s čimer so želeli povečati donosnost ter bolj zadovoljiti zahteve lokalnih pravilnikov in občinskih predpisov kot raznolike potrebe skupnosti (Ford, 1999). Uničenje tradicionalne zasnove ulic in trgov za zadovoljevanje potreb osebnega prometa, strogi predpisi namenske rabe zemljiščc, ki so ločili službene, stanovanjske in zabavne dejavnosti, in zaton pojma javnega prostora na račun privatizacije gradnje so prispevali k oblikovanju nedružabnih in nečloveških sosesk.

Po pojavu urbanističnega oblikovanja v 60. letih 20. stoletja so v ospredje ponovno stopili duh, vrednote in dobre lastnosti stanovanjske soseske. Okrepilo se je sodelovanje stanovalcev in zastopniško načrtovanje, kar je pripeljalo k razvoju novega urbanizma. Ta je pri načrtovanju sosesk zagovarjal uravnotežen nabor človekovih dejavnosti (bivanje, nakupovanje, služba, šola, verski obredi, rekreacija in podobno), do katerih lahko prebivalci dostopajo peš (so pet minut hoje proč oziroma v polmeru pol kilometra), ter oblikovanje javnih prostorov in goste mreže dobro povezanih ulic (Duany in Zyberk, 1994). Drugi so poskušali doseči raznolik, živahen, varnejši in ustreznejši javni prostor, in sicer $z$ mešano rabo zemljišč, visoko gostoto pozidave in gostim urbanim tkivom (Yau, 2011), vključno z zagotavljanjem lokalnih delovnih mest in sistema javnega potniškega prometa, ki bi pomagali razviti lokalno identiteto ter občutek pripadnosti skupnosti in kraju (Lennard in Lennard, 1995; Roseland, 1998). Učinkovita soseska z jasno, popolno in dosledno politično in upravno strukturo bi zato morala zagotavljati najnujnejše življenjske in družbene storitve, kot so majhna trgovina z živili, lokalni park z igriščem, gasilska in policijska postaja, pošta in prostor za srečanja $\mathrm{v}$ osnovni šoli ali rekreativnem centru, $v$ katerem potekajo tudi različne dejavnosti skupnosti. V splošnem lahko stanovanjske soseske 
opišemo (Coleman, 1978; Lachman in Downs, 1978; Rodwin in Hollister, 1984; Galster, 1987) kot: (a) homogena območja s skupnimi demografskimi ali stanovanjskimi značilnostmi; (b) območja, ki imajo lahko različne značilnosti, vendar imajo njihovi prebivalci občutek skupne identitete oziroma skupne politične in družbene usmerjenosti; (c) nepremičninske podtrge in (d) majhne območne enote, za katere ni nujno, da sploh imajo katero od naštetih značilnosti. Ti dejavniki povzročajo, da so soseske privlačne in cenovno dostopne samo določenim skupinam prebivalstva.

Družbeno-kulturni vidik teorije o soseskah se nanaša na oblikovanje občutka pripadnosti skupnosti. Soseska svojim prebivalcem nudi prostor, na katerem lahko vzgajajo otroke, zadovoljijo svoje potrebe po druženju in razvijejo intimne odnose (Ho idr., 2012), zaradi česar krepi njihov občutek pripadnosti skupnosti in državljanski ponos (Von, 1978), povečuje njihov »občutek varnosti in pripadnosti « ter posameznika $s$ pomočjo podpore in storitev povezuje z družbo (Bartuska, 1994). Geografska bližina (lokacija), družbena celota ali kohezija (družbeno merilo; Davis, 1949) in enaki osnovni pogoji življenja v skupnosti (navezanost na skupnost) so bistveni dejavniki, ki oblikujejo skupnost (MacIver in Page, 1955), na katero vplivajo velikost, gostota in heterogenost (Wirth, 1964). Zato posamezna skupnost potrebuje (a) določeno število gospodinjstev, zgoščenih na omejenem geografskem območju; (b) precejšnjo mero družbene interakcije med stanovalci in (c) občutek pripadnosti skupnosti ali drug drugemu. Skupnost določene soseske lahko dojemamo tudi na podlagi lastnosti in pogledov njenih prebivalcev (pristop na mikroravni) ali pa na podlagi formalnih organizacij in ustanov, ki preučujejo skupnost $\mathrm{v}$ šišem kontekstu (pristop na makroravni; Downs, 1981).

Soseske v starem jedru Katmanduja, ki so se izoblikovale v obdobju dinastije Mala, lahko najbolje predstavimo z družbeno-kulturnega vidika. Hiše so bile zgrajene tesno druga ob drugi okrog dvorišča (dvoriščni tip), sobe v njih pa so bile urejene navpično; zaradi tega so bile te soseske gosto pozidane, skupna območja pa so obkrožale posamezne hiše. Dvorišča in budistični samostani (nep. vihara) so kot polzasebna območja z družbeno-verskimi objekti, kot so templji, svetišča (nep. čajtja), pitniki, vodnjaki in gostišča (nep.pati), postali shajališča, na katerih se ob različnih delih dneva družijo ljudje različnih starosti: zgodaj zjutraj tam molijo starejši ljudje, popoldne tam gospodinje sušijo žito in perejo perilo, zvečer pa se tam igrajo otroci oziroma kramljajo odrasli. Ženske so polzasebna območja, kot so glavne ulice, stranske ulice med hišami in dvorišča okrog hiš, razumele kot dragocen prostor, ki upravičeno pripada njim in njihovim otrokom, na katerem lahko klepetajo s sosedi, pazijo otroke in opazujejo, kaj počnejo ljudje v soseščini (Segovia, 1997). Verski objekti, kot so dvignjene kvadratne ploščadi (nep. dabali) in gostišča, so se uporabljali za razkazovanje podob bogov in boginj, izvajanje verskih plesov in iger ter za molitve (nep. bhadžan in kirtan). Ti prostori so povezovali zasebno in javno življenje v skupnosti, $s$ čimer so se krepile družbene vezi. Pomembna mesta, kot so bila tista, ki jih je varoval demon (nep. čbvasa), in zasebna območja pred hišami, ki so bila namenjena javni rabi (nep. lačbi), dodajajo kulturni pomen ulicam in javnim trgom (Shrestha, 2011).

Družbeni sistem sosesk, v katerih na enem kraju živijo ljudje istega poklica ali klana, je okrepil socialno mrežo in delovno storilnost, medtem ko je kulturna praksa z izvajanjem tradicionalnih obredov in s praznovanjem številnih praznikov okrepila vezi v skupnosti; $s$ tem se nista povečali samo medsebojna pomoč in skrb za celotno skupnost, temveč se je okrepil tudi občutek lastništva in pripadnosti skupnosti. Zaradi družbene delitve ljudi na podlagi poklica (džata) in kaste (dotakljivi in družbeno nedotakljivi) ter posledične umeščenosti njihovih stanovanj v mestu glede na vrsto, velikost in slog se je znotraj heterogenega mesta oblikovala homogena skupnost $\mathrm{z}$ dobrimi možnostmi za zaposlitev in zaslužek.

Grajeno tkivo mesta sta sestavljala dva osnovna elementa: zaprti urbani bloki dvo- in trinadstropnih hiš, zgrajenih tesno druga ob drugi okrog dvorišč ali budističnih samostanov (arhitekturna sloga, znana kot bahal in bahil), ter mreža ozkih stranskih ulic in ulic za pešce, vključno z javnimi trgi in dvorišči, ki so te bloke povezovali; ta dejavnika sta ustvarjala vzorec izmenjujočih se praznih in pozidanih delov (Shrestha, 2011). Dejavniki, povezani z višino zgradb (opečnato pročelje, navpična lesena okna in neravne strehe, pri čemer so robovi streh bolj ali manj na isti višini), ter razmerje med širino ulic in višino zgradb $\mathrm{v}$ razmerju od $1: 1$ do $1: 2$ so dajali vtis ograjenosti ulic, njihova velikost pa je ustrezala merilu človeka (ang. human scale). Zaporedje posebnih prostorskih učinkov, ki so nastali zaradi teh lastnosti, in enotna kompozicija vzbujata pri obiskovalcih začudenje, vznemirjenje, pričakovanje in pridih skrivnostnosti. Skupni življenjski slog, uporaba lokalno razpoložljivih gradbenih materialov in podobna metodologija gradnje so prispevali k enotnemu arhitekturnemu slogu. Manjša odstopanja so se pojavljala samo pri kakovosti materialov, izvedbi in končnih delih na pročeljih. Skupni prostor pred posameznimi hišami je bil del lokalne arhitekture in brez njega posamezni objekti ne bi mogli delovati kot hiše. Tradicionalne hiše so bile poleg tega tudi prilagojene podnebnim razmeram. Toplejša zgornja nadstropja in dvorišča so se uporabljala podnevi, najvišje nadstropje in pritličje pa sta stanovalce varovala pred nočnim zimskim mrazom. Zaradi debelih zidov, ki so bili zgrajeni iz opeke, sušene na soncu, in znotraj ometeni z blatom, ter tal iz blata in lesa so te hiše izgubljale zelo malo toplote.

Posameznikove izkušnje, kulturno ozadje, družbeno okolje in fizično stanje določajo odnos med človekovim doživlja- 
njem in vêdenjem ter grajeno obliko (Proshansky, 1970; Yau, 2012), ta pa oblikuje življenje stanovalcev. Pojem kulture kot sistema skupnih pomenov (Hall, 1966; Greetz, 1973) in standardiziranih javnih vrednot določene skupnosti (Douglas, 1966) ustvarja vrednote in norme, ki so vgrajene v človekovo vêdenje in oblikujejo prostore, ki jih ljudje uporabljajo v vsakdanjem življenju (Coolen in Ozaki, 2004). Na podlagi pregleda obsežne literature o različnih vidikih stanovanjskih sosesk smo oblikovali teoretični okvir, sestavljen iz teh treh elementov: (a) stanovanjska soseska z vidika kraja: velikost in oblika soseske, hierarhija ulic in javnih prostorov, arhitekturni pomen; (b) stanovanjska soseska z vidika ljudi: priložnost druženja ter socialne mreže in ustanove; (c) stanovanjska soseska $\mathrm{z}$ vidika pomena (ki ljudi povezuje $s$ krajem): občutek pripadnosti kraju in skupnosti ter dnevne dejavnosti in kulturne funkcije.

\section{Raziskovalna metodologija in izbor stanovanjskih sosesk}

V raziskavi smo uporabili različne metode. Najprej smo kritično pregledali obsežno mednarodno in domačo literaturo o stanovanjskih soseskah, nato pa smo izbrane soseske večkrat obiskali, da bi preučili različne družbeno-kulturne dejavnosti, ki potekajo ob različnem času. Tretjič, pripravili smo vprašalnik z 29 vprašanji o različnih vidikih sosesk. V vsaki soseski smo izvedli anketo v 25 gospodinjstvih. Čeprav je bilo število anketirancev za tako raziskavo na prvi pogled majhno (25 gospodinjstev na vsakem preučevanem območju, pri čemer smo odgovore prejeli v 90 do $100 \%$ ), je - kljub časovni omejenosti in omejenim virom, nizki javni osveščenosti in izobrazbi ljudi ter njihovemu prevladujočemu odporu do razkrivanja podatkov - število ljudi, ki se je odzvalo na anketo, zadoščalo, da smo lahko ugotovili, kaj stanovalci menijo o svoji soseski. Ker vsi anketiranci niso odgovorili na vsa vprašanja, smo odstotek izračunali na podlagi števila vseh dejansko izpolnjenih vprašanj. Četrtič, opravili smo pogovore z zaposlenimi v občinskih in okrajnih uradih ter lokalnih socialnih ustanovah.

Za primerjalno raziskavo (preglednica 1) smo izbrali štiri stanovanjske soseske v Katmanduju, ki so bile načrtovane in zgrajene na podlagi različnih modelov in $\mathrm{v}$ različnih okoliščinah, in sicer (a) projekt gradnje stanovanjske soseske Kulešvor (ang. Kulesvor Housing Project, v nadaljevanju: KHP), (b) projekt skupnega urejanja zemljišč v predelu Gongabu (ang. the Gongabu Land Pooling Project, v nadaljevanju: GLP), (c) stanovanjsko naselje Sun Rise Home (v nadaljevanju: SRH) ${ }^{[3]}$ in (d) naselje na trgu Mandžušri (ang. Manjushree Tole, v nadaljevanju: MST). Soseske se ne razlikujejo samo po lokaciji, fizičnem videzu, gostoti prebivalstva in rabi tal, ampak tudi po skupnostih, ki tam živijo.

Projekt gradnje stanovanjske soseske Kulešvor na metropolitanskem območju Katmanduja (KMC) v okraju št. 14 je konec 70. let 20. stoletja financirala nepalska vlada v sklopu programa za prostor in storitve, da bi zagotovila stanovanja javnim uslužbencem. Območje skupnega urejanja zemljǐ̌č v predelu Gongabu na severnem obrobju okraja KMC št. 29 je konec 80. let 20. stoletja prav tako načrtovala vlada z uporabo metode za skupno urejanje zemljišč, pri čemer sta bila njena glavna cilja nadzorovanje nenačrtnega širjenja mesta ter zagotavljanje osnovnih storitev in socialnih dobrin na načrtovanem območju. Pobudo za projekt gradnje stanovanjske soseske Sun Rise Home na obrobju okraja št. 9 submetropolitanskega območja Lalitpurja je leta 1997 sprožil zasebni sektor po sprejetju zakona o lastništvu skupnih stanovanj 2054 (uradni list Republike Nepal z dne 15. aprila 2003), namenjen pa je bil zgornjemu srednjemu razredu oziroma prebivalcem $\mathrm{z}$ visokim ekonomskim statusom. Trg Mandžušri se nahaja v starem jedru okraja KMC št. 21. Gre za staro stanovanjsko naselje iz obdobja dinastije Mala, v katerem lahko še vedno najdemo veliko zgodovinskih spomenikov in primerkov kulturne dediščine.

Preglednica 1: Primerjava lokacijskih parametrov izbranih sosesk

\begin{tabular}{lllll}
\hline Parameter & KHP & GLP & SRH & MST \\
\hline lokacija & $\begin{array}{l}\text { Kulešvor - KMC, okraj št. 14 } \\
\text { (mesto) }\end{array}$ & $\begin{array}{l}\text { Gongabu - KMC, okraj } \\
\text { št. 29 (obrobje) }\end{array}$ & $\begin{array}{l}\text { Balkumari - LSMC, okraj } \\
\text { št. 9 (obrobje) }\end{array}$ & $\begin{array}{l}\text { trg Mandžušri - KMC, okraj } \\
\text { št. 21 (središče mesta }\end{array}$ \\
\hline vrsta projekta & $\begin{array}{l}\text { vladni program za prostor in } \\
\text { storitve }\end{array}$ & skupno urejanje zemljišč & zasebna stanovanja & starodavno naselje \\
\hline površina & 522 ropanijev (26,5 ha) & 280 ropanijev (14,2 ha) & 45 ropanijev (2,3 ha) & 100 ropanijev (5,1 ha) ${ }^{[4]}$ \\
\hline obdobje gradnje & $1977-1987$ & $1988-1996$ & $2002-$ & $\begin{array}{l}\text { obdobje dinastije Mala (13.- } \\
\text { 18. stoletje) }\end{array}$ \\
\hline izvajalec & vlada & vlada & zasebni sektor &
\end{tabular}

Opomba: KMC = metropolitansko območje Katmanduja (ang. Kathmandu Metropolitan City), LSMC = submetropolitansko območje Lalitpurja (ang. Lalitpur Sub-Metropolitan City)

Vir: urad za stanovanja in mestni razvoj (ang. Department of Housing and Urban Development; brez datuma); urad za mestni razvoj in gradnjo (ang. Department of Urban Development and Building Construction, 2003); metropolitansko območje Katmanduja (2001); podjetje Oriental Construction and Development (brez datuma) 


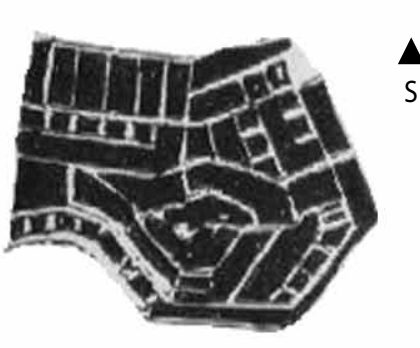

KHP

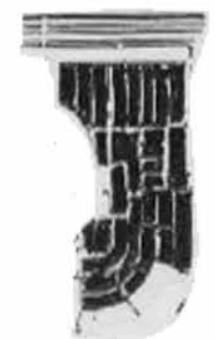

GLP

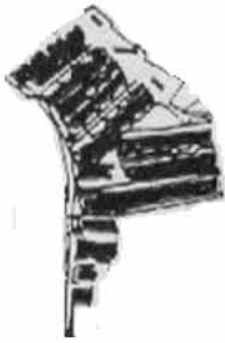

$\mathrm{SRH}$

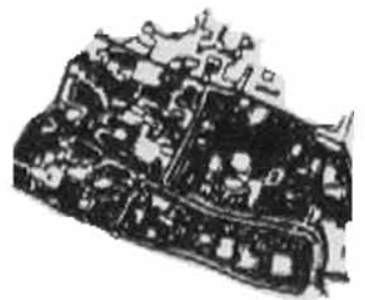

MST

Slika 1: Primerjava urbanih tkiv različnih sosesk (ilustracije: Bijaya K. Shrestha)

\section{Primerjalna študija izbranih stanovanjskih sosesk}

\subsection{Stanovanjske soseske kot kraji}

\subsubsection{Velikost, obseg in povezanost z okolico}

Soseska je učinkovita, če ima med 500 in 10.000 prebivalci in najmanj 150 stanovanjskih enot (kar naj bi bilo dovolj za delovanje lokalnih trgovin in osnovne šole; Gans, 1962). SRH, ki obsega 164 enot, ima 820 prebivalcev $^{[5]}$ in je najmanjša soseska, medtem ko sta soseski KHP in GLP od nje 5-krat oziroma 2,5-krat večji. Največja skupnost od vseh je MST (preglednica 2). Z vidika grajenega okolja je MST dvakrat večja od SRH, medtem ko KHP in GLP obsegata 11,5- oziroma 6-krat večjo površino. V primerjavi z GLP je gostota prebivalstva v SRH 2,5-krat večja, v MST pa 8,5-krat večja (gostota prebivalstva v KHP pa znaša 159 ljudi/ha, kar pomeni, da je najredkeje naseljena soseska $\mathrm{z}$ bruto gostoto prebivalstva $143 \mathrm{ljudi} / \mathrm{ha}$ ). Majhni urbani bloki, ki niso daljši od 90 do 135 metrov, omogočajo boljšo prehodnost in preglednost ulic (Bentley idr., 1985), zagotavljajo večje število križišč in v ravni vrsti urejenih stavb, dostopnih z ulice, omogočajo pa tudi razvoj raznolike rabe tal in gradnjo različnih vrst zgradb, zaradi česar so primerni za gradnjo stanovanj.
Povprečna velikost urbanega bloka v KPH in MST znaša približno 25 ropanijev, vendar obstajajo med soseskama velike razlike v skupnem številu parcel na sosesko in povprečnem številu parcel na urbani blok. KHP ima skupno 842 parcel in $v$ povprečju 40 parcel na urbani blok, v MST pa znašati ti številki 1.376 in 344. Tako KHP kot MST imata različne urbane bloke s poljubno prostorsko orientacijo (slika 1). Zanimivo je, da so urbani bloki v GLP in SRH običajno dolgi in ozki, vendar potekajo v nasprotni smeri. Soseski potrebujeta jasne meje, da bi lahko določili in ohranjali svojo identiteto. Povezovanje z okoliškimi območji z vidika postavitve ulic, urbanih blokov, gostote prebivalstva in rabe tal omogoča bolj tekoč promet, boljšo orientacijo in boljši razgled, kar zmanjšuje razlike med starimi in novimi naselji.

KHP in GLP sta bili načrtovani tako, da imajo parcele in ulice v urbanih blokih geometrično obliko ter se tako močno razlikujejo od okoliških nenačrtno (in spontano) rastočih stanovanjskih in trgovskih območij. SRH pa obdaja zid, zaradi katerega dobimo občutek, kot da je odrezana od svoje okolice. Nobena od teh sosesk nima jasnega središča in robov (razen zidu, ki obdaja SRH), vendar lahko na podlagi vidnih razlik $\mathrm{v}$ ulicah in urbanih blokih določimo meje posamezne soseske. Poleg tega glavne prometne poti, kot sta mestna obvoznica ter cesta, ki povezuje območje Thamel in ulico Samakhuši Marg,

Preglednica 2: Primerjava fizičnih lastnosti sosesk

\begin{tabular}{|c|c|c|c|c|}
\hline Parameter & KHP & GLP & SRH & MST \\
\hline skupna pozidana površina & $\begin{array}{l}522 \text { ropanijev }(26,5 \mathrm{ha}) \\
(11,5 \times \mathrm{SRH})\end{array}$ & $\begin{array}{l}280 \text { ropanijev }(14,2 \mathrm{ha}) \\
(6,2 \times \mathrm{SRH})\end{array}$ & $\begin{array}{l}45 \text { ropanijev } \\
(2,3 \mathrm{ha}) \\
(1 \times \mathrm{SRH})\end{array}$ & $\begin{array}{l}100 \text { ropanijev } \\
(5,1 \mathrm{ha}) \\
(2,2 \times \mathrm{SRH})\end{array}$ \\
\hline skupno število urbanih blokov & $21^{[6]}$ & 26 & 9 & 4 \\
\hline $\begin{array}{l}\text { povprečna velikost urbanega } \\
\text { bloka }\end{array}$ & $\begin{array}{l}24,85 \text { ropanijev } \\
(5 \times \text { SRH) }\end{array}$ & $\begin{array}{l}\text { 10,77 ropanijev } \\
(2,1 \times \mathrm{SRH})\end{array}$ & $\begin{array}{l}5 \text { ropanijev } \\
(1 \times \mathrm{SRH})\end{array}$ & $\begin{array}{l}25 \text { ropanijev } \\
(5 \times \mathrm{SRH})\end{array}$ \\
\hline \multirow{2}{*}{ skupno število parcel } & 842 & 406 & 164 enot & 1.376 hiš \\
\hline & $(5,13 \times \mathrm{SRH})$ & $(2,5 \times \mathrm{SRH})$ & $(1 \times \mathrm{SRH})$ & $(8,4 \times \mathrm{SRH})$ \\
\hline število parcel na urbani blok & 40 & 16 & 18 & 344 \\
\hline gostota prebivalstva & $\begin{array}{l}159 \text { ljudi/ha } \\
(1,1 \times \mathrm{GLP})\end{array}$ & $\begin{array}{l}143 \text { ljudi/ha } \\
(1 \times \text { GLP })\end{array}$ & $\begin{array}{l}356 \text { ljudi/ha } \\
(2,5 \times \mathrm{GLP})\end{array}$ & $\begin{array}{l}1.185 \text { ljudi/ha } \\
(8,3 \times \mathrm{GLP})\end{array}$ \\
\hline usmerjenost urbanega bloka & $\begin{array}{l}\text { poljubna } \\
\text { (v vse smeri) }\end{array}$ & $\begin{array}{l}\text { vzhod-zahod } \\
\text { (večinoma) }\end{array}$ & $\begin{array}{l}\text { sever-jug } \\
\text { (večinoma) }\end{array}$ & $\begin{array}{l}\text { v vse smeri } \\
\text { (zaradi dvorišča) }\end{array}$ \\
\hline
\end{tabular}




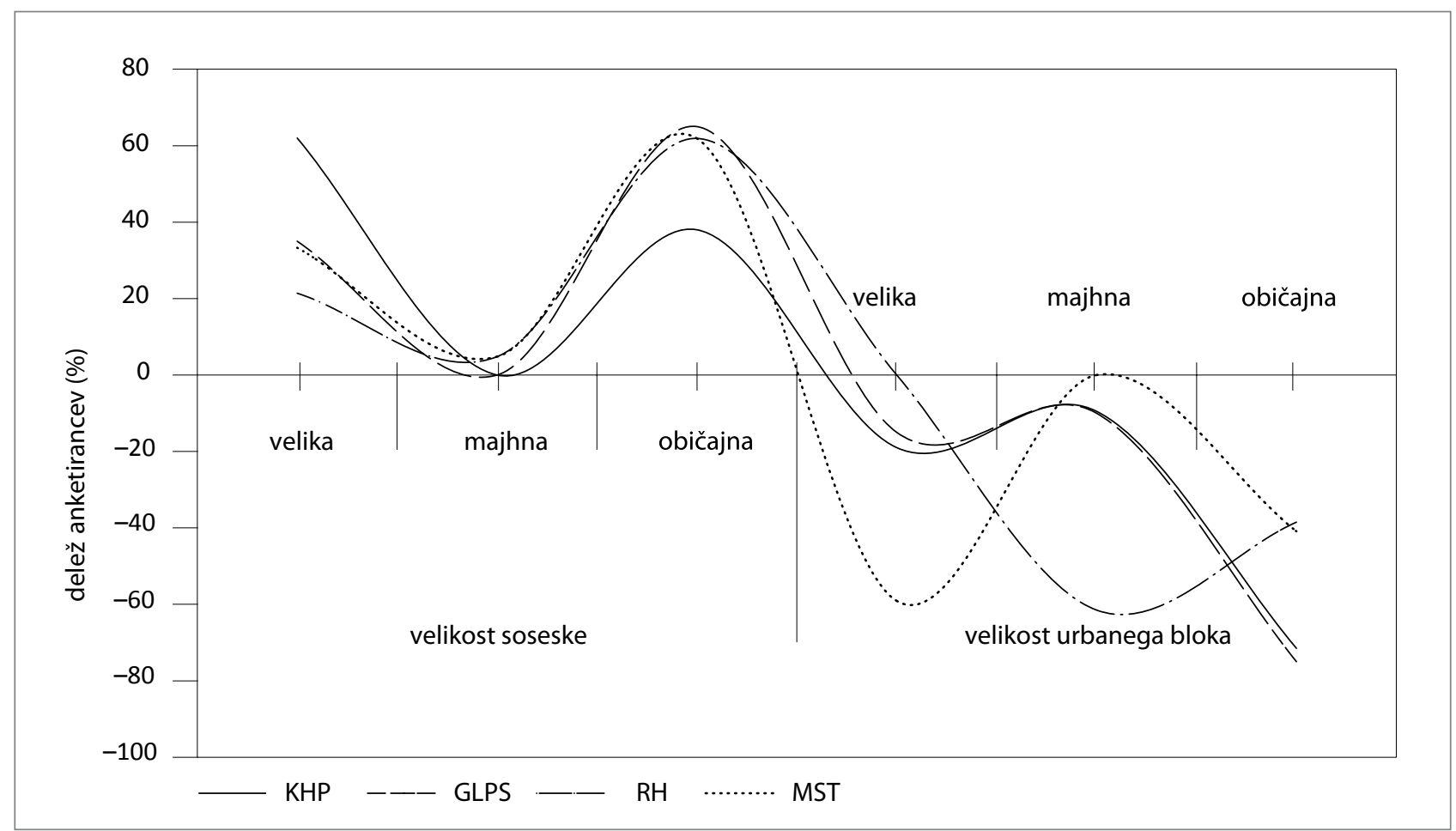

Slika 2: Obseg sosesk

omejujejo sosesko GLP, cesta med predelom Kalimati in ulico Kulešvor ter cesta med Kalimatijem in ulico Kalanki pa določata lokacijo KHP. Samo MST, ki je del starega naselja, harmonično sobiva z okoliškimi območji, pri čemer tempelj Mandžušri deluje kot središče, živahni območji templja Džajši Deval in trga Lagan pa kot obrobje skupnosti.

V anketi je večina vprašanih (62\%) v soseski KHP odgovorila, da živi v veliki soseski, medtem ko je podoben odstotek vprašanih v drugih treh soseskah odgovoril, da so njihove soseske ustrezne velikosti in ustreznega obsega (slika 2). Presenetljivo je, da noben prebivalec sosesk KHP in GLP ne meni, da sta njihovi soseski majhni, v drugih dveh soseskah pa je svojo so-

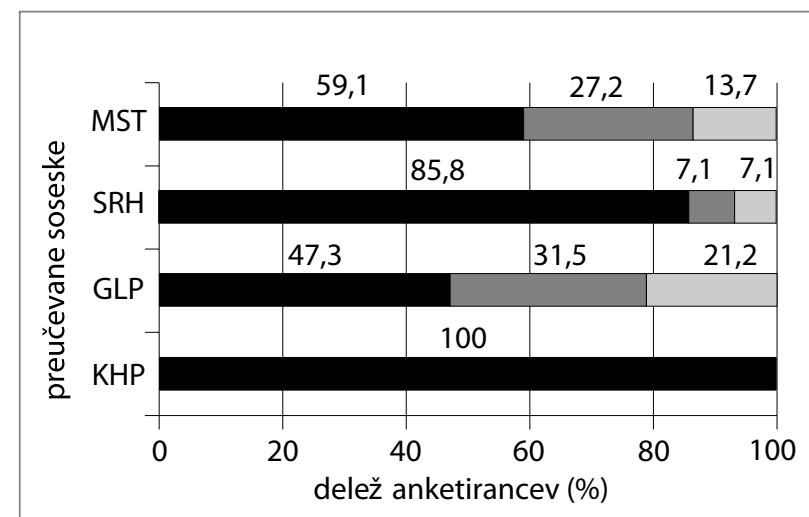

dobro povezana $\square$ nepovezana $\square$ drugo

Slika 3: Povezanost sosesk z okoliškimi območji sesko kot majhno dojemal samo zanemarljiv odstotek prebivalcev. Razen v SRH tudi samo zanemarljiv odstotek prebivalcev vseh sosesk meni, da imajo majhne urbane bloke. Čeprav velik delež prebivalcev KHP (100 \%) in SRH (85,8 \%) meni, da se njihove stanovanjske soseske dobro povezujejo z okoliškimi območji, se približno polovica vprašanih v MST (40,1\%) in $\operatorname{GLP}(52,7 \%)$ ne strinja s tem (slika 3).

\subsubsection{Hierarhija ulic in odprtih prostorov}

Ulice in javni prostori imajo simbolno, slovesno in politično vlogo ter niso samo fizični prostori, namenjeni gibanju ljudi in dobrin, temveč služijo tudi različnim dejavnostim, kot so druženje, sodelovanje, izmenjava storitev, zabava in spremljanje različnih dogodkov (Jacobs, 1993; Gehl, 1987). Lahko jih ocenjujemo na podlagi fizičnih parametrov, mikroklimatskih meril ter javnih dobrin in dejavnosti, povezanih z njimi (Heng in Chan, 2000).

Ulice v KHP in GLP so urejene tako, da ne upoštevajo lokalnih znamenitosti, ne omogočajo razgleda na obdajajoče gore in so slabo povezane s sosednjimi območji. Samo nekaj ulic v KHP je na primer povezano s cesto, ki vodi od ulice Kulešvor do območja Balkhu, in le ena ulica je povezana s cesto Kalimati-Kalanki, na kateri je na voljo javni prevoz. Podobno je tudi GLP s sosednjimi območji povezana samo z eno ulico, ki na severu vodi do mestne obvoznice, nekaj ulic pa sosesko povezuje s cesto Thamel-Samakhuši. Površina, ki jo zasedajo ulice, je v teh soseskah premajhna $(14,3 \% \mathrm{v}$ KHP in $17,5 \% \mathrm{v}$ 
GLP; preglednica 3), hierarhija ulic je slaba, med seboj so slabo povezane, zaradi dolgih urbanih blokov brez prečnih prehodov so slabo prehodne in imajo slabo urejena križišča, v katerih reševalna vozila le težko zavijajo.

Te ulice ne ustvarjajo občutka ograjenosti, saj se stavbe na obeh straneh ceste razlikujejo po višini, arhitekturnem slogu in tem, kako daleč od glavne ulice so postavljene; poleg tega nimajo prepoznavnih središč dejavnosti ali opaznih objektov na križiščih, pločnikov niti druge osnovne infrastrukture, kot so smetnjaki, klopi, drevesa in ulične svetilke, zaradi česar so neprijazne za pešce. Sprehajanje po teh ulicah je monotono in dolgočasno, hitro lahko kam zaideš, ponoči pa so ulice nevarne, še posebej za ženske. SHR zajema 6 slepih ulic, ki so široke 5 metrov in povezane z glavno ulico, ki celotno sosesko povezuje z zunanjo javno cesto. Čeprav so te notranje ulice lepo urejene in čiste ter imajo dobro razmerje med širino ulic in višino stavb $(1: 2)$, se le redko uporabljajo za kaj drugega kot parkiranje in povezavo do stanovanj. Pri načrtovanju zasebnih stanovanj je oblikovanje dobro povezanih ulic s središči dejavnosti na križǐšcih in pomembnim objektom na koncu ulice manj pomembno. Ulična mreža v soseski MST (ozke neaksialne ulice, ki vodijo do dvorišč in ozkih stranskih ulic ter na koncu pripeljejo do posameznih hiš), ki je bila zasnovana pred pojavom avtomobilov, je imela jasno določeno hierarhijo, ki je temeljila na verskih funkcijah. Občutek ograjenosti, velikost glede na merilo človeka in prostorsko zaporedje različnih prizorov so zagotovili s tem, da so obdržali razmerje med širino ulice in višino stavb v želenih okvirih $(1: 1,5)$ ter da so na konec ulice postavili opazen objekt in uporabili enotno kompozicijo stavb $\mathrm{z}$ vidika višine in prostornine, arhitekturnega sloga ter uporabljenih materialov in gradbene tehnologije. Vdor prometa na ulice, parkirna mesta, nenačrtna gradnja ter obnova stavb in spremembe v njihovi rabi pa so uničili prejšnje dobre lastnosti ulic v MST.

V vseh preučevanih soseskah načrtovanje in oblikovanje odprtih prostorov nista zadovoljiva, v MST pa je večfunkcijska raba

Preglednica 3: Primerjava odprtih prostorov in ulic v preučevanih soseskah

\begin{tabular}{lllll}
\hline Parameter & KHP & GLP & SRH & MST \\
\hline $\begin{array}{l}\text { površina odprtih pro- } \\
\text { storov (\%) }\end{array}$ & 4,4 & 5,2 & 4 & $10-12$ \\
\hline površina ulic (\%) & 14,3 & 17,5 & 15 & $3-5$ \\
\hline širina ulic (v metrih) ${ }^{[7]}$ & $2,3,4,5,7,5$ & $4,6,8$ & 5 & 4,6 \\
\hline število križišč & 40 & 51 & 7 & 8 \\
\hline $\begin{array}{l}\text { razmerje med širino in } \\
\text { višino ulice (približek) }\end{array}$ & $1: 1,3$ & $1: 1,7$ & $1: 2$ & $1: 1,5$ \\
\hline
\end{tabular}

Vir: urad za stanovanja in mestni razvoj (brez datuma); urad za mestni razvoj in gradnjo (2003); metropolitansko območje Katmanduja (2001); podjetje Oriental Construction and Development (brez datuma). skupnih območij zaradi različnih razlogov celo močno ogrožena. Prvič, število javnih prostorov, določenih za načrtovana območja, je ni dovolj veliko, da bi lahko zadovoljilo raznolike potrebe različnih starostnih skupin prebivalcev (glej preglednico 3). Urbani javni prostori v KHP pokrivajo 4,5\%, v SRH pa $4 \%$ celotne pozidane površine v soseski, kar je enakovredno slabi tretjini obstoječih javnih prostorov v MST; to ni dovolj, da bi lahko na teh prostorih omogočili različne funkcije (na primer tiho in mirno območje za odrasle, varno zasebno območje za ženske ter območje za rekreacijo in igro otrok in mladostnikov). Drugič, oblika in lokacija teh prostorov nista primerni niti ustrezni. Dejansko so odprti prostori območja nepravilnih oblik in velikosti, ki so ostala po parcelaciji komunalno opremljenih zemljišč in načrtovanju ulic na najboljšsh lokacijah (slika 4). Odprti prostori v KHP (trikotna parcela približno v sredini soseske in majhne pravokotne parcele na obrobju) in GLP (pet različnih majhnih pravokotnih parcel ob daljnovodu) niso uporabni samo zato, ker so razdrobljeni, ampak tudi zaradi prometnih ulic, ki jih obkrožajo. Podobno tudi izolirana vogalna parcela pod daljnovodom, obkrožena s parkirišči, namenjenimi obiskovalcem bližnjega otroškega igrišča, nima velike uporabne vrednosti. Samo v MST se odprti prostori in hiše med seboj dopolnjujejo. Odprti prostori v obliki svetišč, dvorišč in uličnih trgov so del vsakdanjega življenja mestnih prebivalcev, vendar so spremembe v tipologiji stavb in vdor osebnega prometa uničili mrežo javnih prostorov in zmanjšali večstranskost njihove rabe.

Pri izpolnjevanju anketnega vprašalnika so imeli prebivalci preučevanih sosesk različna mnenja o ulicah v svojih soseskah. Večina prebivalcev KHP (62 \%) in SRH (100 \%) meni, da so njihove ulice v dobrem stanju, da omogočajo avtomobilski dostop do vseh hiš, niso prometne ter zato tudi ne preveč hrupne in onesnažene, zaradi česar se jim zdijo praktične in ustrezne. Veliko prebivalcev GLP (32 \%) in MST (54\%) meni, da ulice v njihovih soseskah niso ustrezne, in sicer zaradi mešanja pešcev in vozil, hrupa in onesnaženega zraka ter odlaganja gospodinjskih in gradbenih odpadkov. $V$ vseh soseskah približno petina prebivalcev meni, da so njihove ulice $\mathrm{z}$ vidika ureditve in infrastrukture samo povprečne. Prav tako se v vseh soseskah večina stanovalcev zaveda uporabnosti javnih urbanih prostorov v vsakdanjem življenju. Velik delež prebivalcev KHP (62 \%), GLP (50 \%) in MST (73\%) pa ugotavlja, da njihova naselja nimajo dovolj javnih prostorov ter da ti prostori zaradi slabe lokacije, nepravilne velikosti in oblike ter pomanjkanja osnovne infrastrukture niso funkcionalni (slika 5). Tudi v SRH 43 \% stanovalcev ni zadovoljno z dodeljeno površino javnega prostora.

\subsubsection{Arhitekturni pomen}

Postavitev in oblika stavb določata gostoto stanovanj, pomagata oblikovati javne prostore in izražata družbeno-gospodarski 


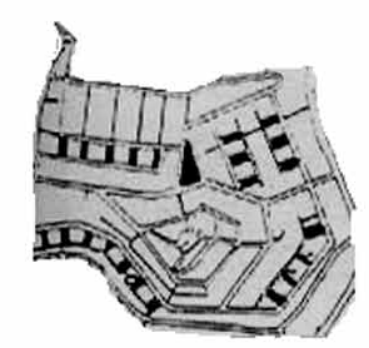

KHP

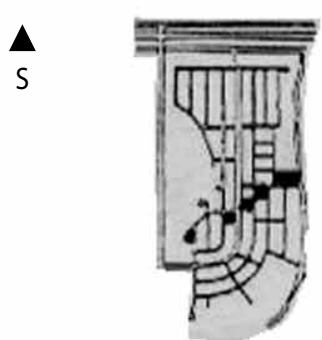

GLP

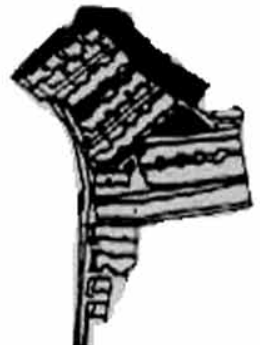

$\mathrm{SRH}$

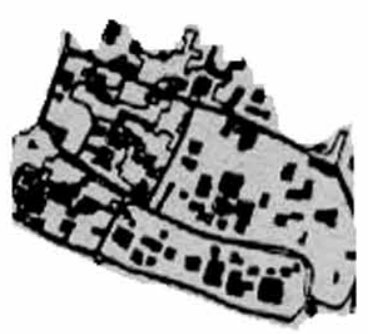

MST

Slika 4: Primerjava ureditve ulic in odprtih prostorov v preučevanih soseskah (ilustracije: Bijaya K. Shrestha)

položaj stanovalcev. Poleg tega naj bi tipologija stavb upoštevala podnebne razmere in družbeni razvoj. Različna tipologija stavb v posameznih soseskah pa ima številne posledice. Prvič, zaradi stavb v KHP in GLP, ki so na parcelah postavljene tako, da so od ulice enako oddaljene $\mathrm{z}$ vseh strani (paviljonski tip), je gostota stavb manjša, med stavbami pa so se oblikovali razdrobljeni javni prostori, ki so uporabni samo za razsvetljavo in prezračevanje stanovanj. V MST postavitev stavb okrog skupnega dvorišča (dvoriščni tip ${ }^{[8]}$ ) omogoča večjo gostoto pozidave in oblikovanje skupnega območja, ki ga ograjujejo posamezne stavbe (slika 6). Za SRH je značilna zmerna gostota pozidave, pri kateri so stavbe na parceli postavljene $\mathrm{v}$ vrsti ob ulici (vrstni tip), prostor med stavbami in ulico zadaj pa je majhen.

Drugič, različni prehodi med ulicami in posameznimi zasebnimi hišami so v KHP in GLP ustvarili kaotično pokrajino. $\mathrm{Na}$ isti ulici so nekatere stavbe postavljene daleč nazaj in obdane z zidovi, ki ločujejo javne in zasebne prostore, druge stavbe pa so tik ob cesti in imajo v pritličju trgovine. Poleg tega so velike razlike pri načrtovanju teh vmesnih prostorov. Splošni rezultat je monotono, neurejeno in nepregledno stanovanjsko okolje. Tretjič, tako za KHP kot GLP so značilni trije tipi stavb, ki izražajo spremembe v družbenem okusu in arhitek- turnem slogu: (a) stavbe z nosilnimi zidovi iz opeke (ki so lahko ometeni s cementom ali goli) in ravno streho, ojačeno z armiranim betonom, ter lesenimi okni in vrati, na vrhu okrašenimi s strukturami, ki so podobnih oblik kot čajtje; te stavbe so bile večinoma zgrajene v 80 . letih 20 . stoletja; (b) objekti z nosilnimi stebri iz armiranega betona in najrazličnejšimi okrasnimi elementi (na primer z dorskimi stebri, ki so enojni ali dvojni po višini, s timpanoni in frčadami) na pročeljih (postmoderna arhitektura), ki so se začeli graditi sredi 90. let prejšnjega stoletja, in (c) objekti z nosilnimi stebri iz armiranega betona, dopolnjeni s plastjo tradicionalne opeke, z izrezljanimi lesenimi okni in neravnimi strehami, ki se gradijo v zadnjem času. Novogradnje z različnimi arhitekturnimi slogi in detajli, zgrajene $\mathrm{z}$ različnimi materiali in različno tehnologijo, se slabo skladajo z okoliškimi hišami.

Zanimivo zasnovanim stanovanjem z enotnim slogom gradnje v naselju SRH ni uspelo ustvariti prepoznavne podobe stanovanjske soseske, saj se enake hiše ponavljajo na obeh straneh ulice in tako ni nobene referenčne točke, po kateri bi se bilo mogoče ravnati. Stanovanja v SRH imajo večinoma eno nadstropje ali dve, razporejena pa so v smeri sever-jug. To z vidika temperature ni učinkovito, saj imajo skoraj vse sobe samo eno stransko okno in veliko prostorov (jedilnica, dnevna soba ali

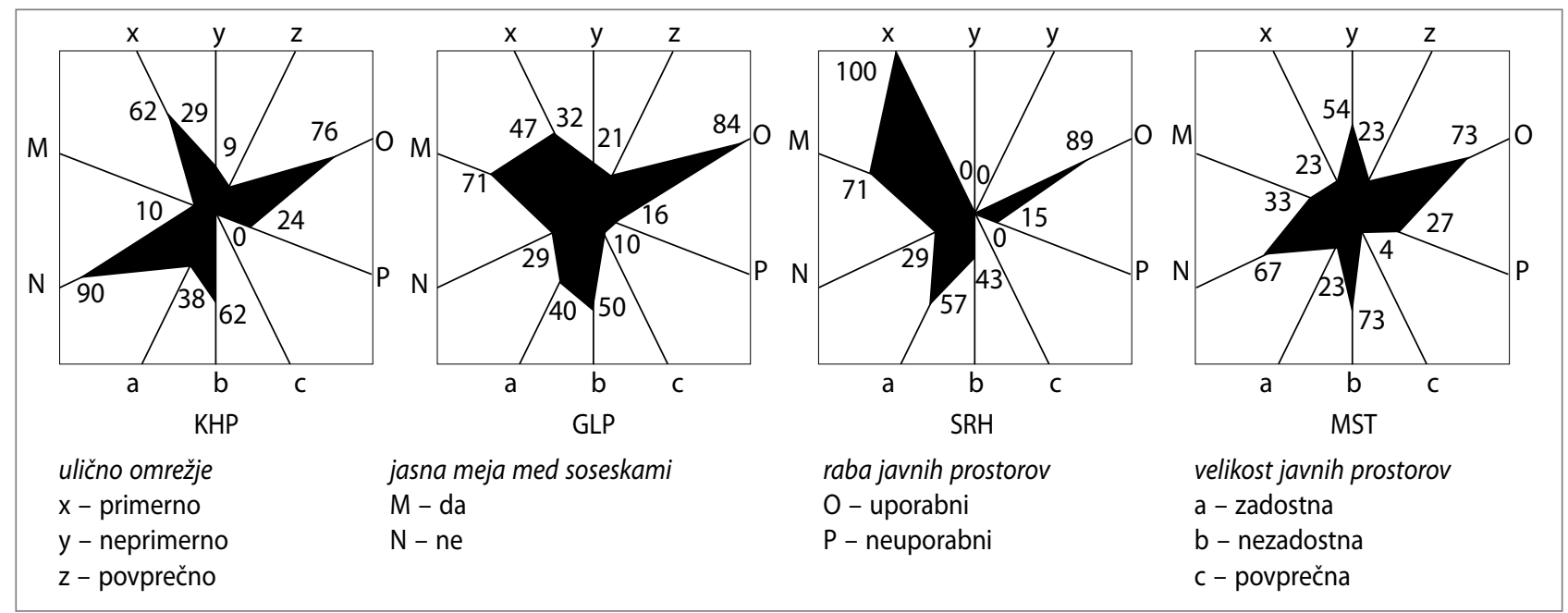

Slika 5: Primerjava mnenj stanovalcev o ureditvi ulic in odprtih prostorih 


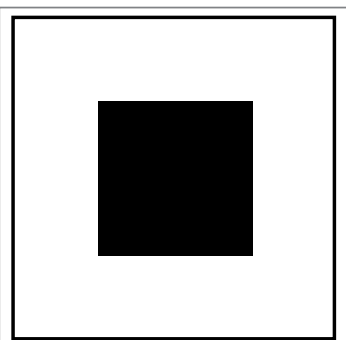

KHP

paviljonski tip

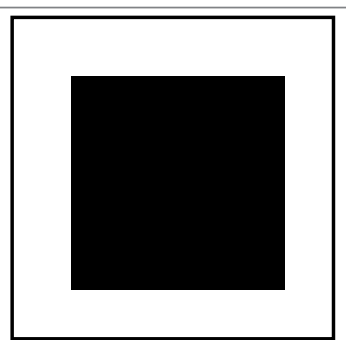

GLP

aviljonski tip

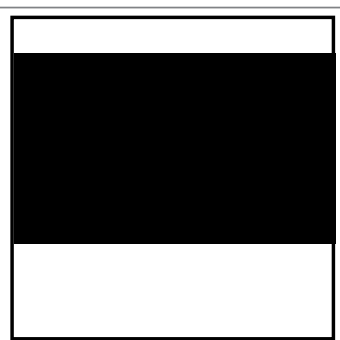

SRH

vrstni tip

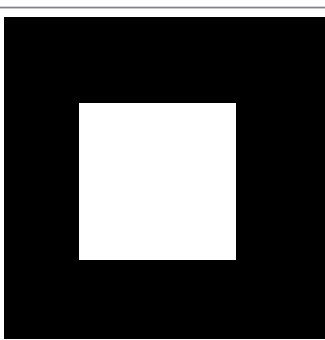

MST

dvoriščni tip

Slika 6: Primerjava tipologije stavb na posamezni parceli v preučevanih soseskah (ilustracije: Bijaya K. Shrestha)

stopnišča), zato ni neposredne svetlobe in urejenega prezračevanja. Obnova tradicionalnih stavb (z dodajanjem nadstropij iz armiranega betona na objekte iz lesa in blata ter s poljubno zazidavo oken in vrat v nosilnih zidovih pročelja) in vse pogostejša gradnja novih hiš (z različnimi temelji, različno visokimi nadstropji, odprtim pritličjem, s štrlečimi etažami od drugega nadstropja naprej, pretirano rabo nekonstrukcijskih okrasnih elementov na pročelju in z velikimi okni s kratkimi stebrički) v MST sta se izkazali kot katastrofalni, saj tovrstne dejavnosti uničujejo prejšnjo arhitekturno kompozicijo, občutek ograjenosti dvorišč in ulic, zmanjšujejo svetlobo in zračnost na sosednjih parcelah in javnih prostorih ter predvsem večajo ranljivost v primeru potresov in požarov (Shrestha, 2002).

$\mathrm{Z}$ anketo so se pokazale razlike $\mathrm{v}$ odgovorih prebivalcev glede stanja stavb v njihovih soseskah. Večina vprašanih $\mathrm{v}$ KHP $(71,4 \%)$ in SRH (64,3\%) meni, da so stavbe v tej soseski v dobrem stanju (slika 7). Noben anketiranec iz teh sosesk ni odgovoril, da so tamkajšnje stavbe v slabem stanju. V soseski MST pa je stanje drugačno: več kot polovica stanovalcev meni, da so stavbe v njihovi soseski v slabem stanju. V GLP pa je $80 \%$ vprašanih odgovorilo, da so stavbe v njihovi soseski samo »povprečne« (ne dobre ne slabe).

Skoraj polovica stanovalcev MST želi ohraniti tradicionalne stavbe oziroma so ji všeč nove stavbe, zgrajene v tradicionalnem slogu, medtem ko si v SRH noben anketiranec v svoji soseski ne želi novih stavb, zgrajenih v tradicionalnem slogu. V KHP in GLP si želi samo majhen odstotek anketirancev v svoji soseski imeti tradicionalne stavbe. Skoraj polovica stanovalcev v teh dveh soseskah bi raje imela stavbe mešanega tipa, kot da bi prevladovali tradicionalni ali moderni objekti. V SRH želi $85 \%$ stanovalcev živeti v modernih stavbah, samo $15 \%$ pa bi jih v svoji soseski raje imelo stavbe mešanega tipa. V MST se za moderne stavbe zanima zelo malo ljudi (14\%). V vseh soseskah pa so stanovalci glede tega, ali bi moral biti pri novogradnjah poudarek na estetskem ali funkcionalnem vidiku, razdeljeni približno na polovico.

\subsection{Socialni vidik sosesk}

Socialni vidik sosesk zajema posameznikovo socialno mrežo, podporo, ki jo dobi od drugih, in možnost interakcije z drugimi člani skupnosti, kar ne krepi samo medsebojne pomoči in skrbi za celotno skupnost, ampak tudi povečuje občutek lastništva in pripadnosti skupnosti. Socialno mrežo tvorijo različne osebe, s katerimi posameznik vzdržuje pomembne odnose (sorodniki, prijatelji, sodelavci in sosedje), medtem ko se družbena podpora nanaša na kakovost teh odnosov (nasveti, spodbuda in kakršna koli pomoč, ki jo posamezniku nudi socialna mreža).

Preglednica 4: Primerjava lastnosti stanovanj

\begin{tabular}{|c|c|c|c|c|}
\hline Parameter & KHP & GLP & SRH & MST \\
\hline $\begin{array}{l}\text { postavitev stavbe na } \\
\text { parceli }\end{array}$ & paviljonski tip & paviljonski tip & vrstni tip & dvoriščni tip \\
\hline usmerjenost & poljubna & $\begin{array}{l}\text { poljubna, vendar večinoma v } \\
\text { smeri vzhod-zahod }\end{array}$ & $\begin{array}{l}\text { večinoma v smeri se- } \\
\text { ver-jug }\end{array}$ & $\begin{array}{l}\text { na vse strani zaradi } \\
\text { dvorišča }\end{array}$ \\
\hline dostop & $\begin{array}{l}\text { z avtom (le redko s potkami } \\
\text { za pešce) }\end{array}$ & z avtom & z avtom (zasebna ulica) & $\begin{array}{l}\text { večinoma peš, nekaj tudi } \\
\text { z avtom }\end{array}$ \\
\hline vrsta stavbe & individualna hiša & individualna hiša & večinoma vrstne hiše & $\begin{array}{l}\text { dvorišča s skupnimi } \\
\text { zidovi }\end{array}$ \\
\hline št. nadstropij & $3-4$ & $3-4$ & $2-3$ & $4-6$ \\
\hline svetloba in zračnost & $\begin{array}{l}\text { večinoma na vseh } 4 \text { straneh, } \\
\text { razen pri hišah, ki so tik ob } \\
\text { cesti, (samo } 2 \text { strani) }\end{array}$ & $\begin{array}{l}\text { večinoma na vseh } 4 \text { straneh, } \\
\text { razen pri hišah, ki so tik ob } \\
\text { cesti, (samo } 2 \text { strani) }\end{array}$ & samo dve strani & samo ena stran ali dve \\
\hline
\end{tabular}




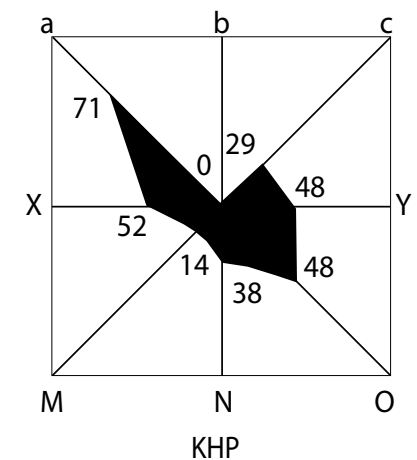

stanje stavb

a - dobro

b - slabo

c - povprečno

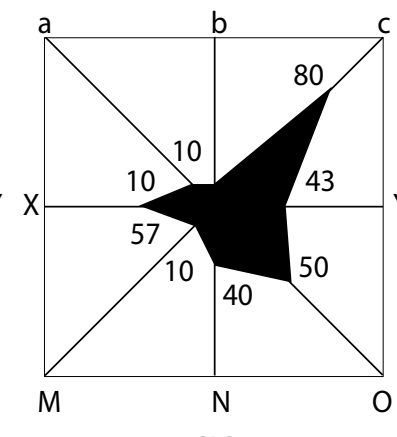

GLP

zasnova novih stavb

$\mathrm{X}$ - estetska

$\mathrm{Y}$ - funkcionalna

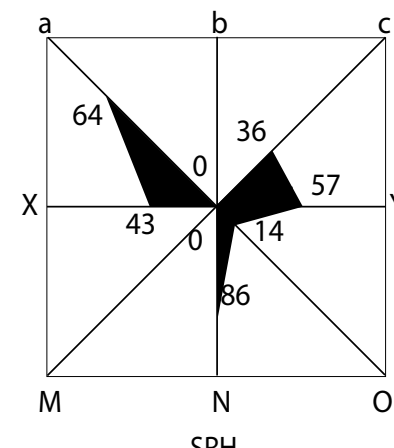

$\mathrm{SRH}$

zaželen slog novogradenj

$\mathrm{M}$ - tradicionalni

$\mathrm{N}$ - moderni

0 - mešani

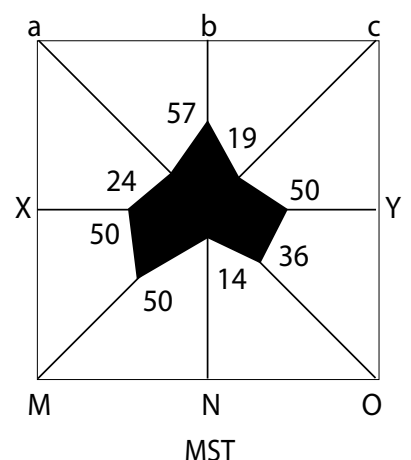

MST

Slika 7: Primerjava odgovorov anketirancev glede stanja stavb, zasnove novih stavb in zaželenega sloga novogradenj

\subsubsection{Socialna mreža, družbena podpora in ustanove v stanovanjski skupnosti}

Družbeni sistemi skupnosti, v katerih na isti lokaciji živijo ljudje z istim poklicem ali iz istega klana, ki je značilen za stari del Katmanduja, je krepil socialne mreže in delovno učinkovitost ljudi, medtem ko je kulturna praksa izvajanja tradicionalnih obredov in praznovanja številnih praznikov pomagala ohranjati družbene vezi in medsebojno podporo znotraj skupnosti. Finančno in institucionalno trajnostnost skupnosti in njihovih družbeno-kulturnih dejavnosti je omogočal sistem guthijev. ${ }^{[9]}$ V MST take posebne razmere ne obstajajo več. Propad sistema guthijev, slabenje kulturne prakse, prepričanj, vrednot in družabno-verskih dejavnosti, razbitje družbene homogenosti (zaradi odseljevanja starih prebivalcev in priseljevanja novih), ${ }^{[10]}$ spremenjen življenjski slog (zaradi prehoda iz agrarne v storitveno in informacijsko družbo) ter večja gostota prebivalstva in stavb so prispevali $\mathrm{k}$ slabenju tradicionalne socialne mreže in zmanjšanju obsega materialne podpore (materialna in finančna pomoč, pomoč pri varstvu otrok in gospodinjskih delih ter podobno) in čustvene podpore (spodbude, možnosti izražanja čustev). Tekmovanje za uporabo omejenih skupnih virov, kot so dvorišča ter skupne pipe in vodnjaki, vdori v zasebnost in prisiljeni ali nezaželeni stiki so prejšnje tesne vezi $\mathrm{v}$ skupnosti spremenili v razmere, $\mathrm{v}$ katerih vlada čustvena in družbena napetost. Neprijaznost sosedov, prepiranje z drugimi člani skupnosti o nepomembnih stvareh, odlaganje odpadkov na poteh in dvoriščih ter motenje zasebnosti drugih na različne načine so običajni prizori v starih soseskah, kot je MST. Ker so bile druge tri soseske zgrajene na neobdelani zemlji v poznejših obdobjih, imajo lahko lokalne organizacije, vključno z okrajnim uradom, odločilno vlogo pri oblikovanju socialnih mrež in družbene podpore. Številne tovrstne ustanove (klub Kulešvora, dobrodelna stanovanjska organizacija za pomoč družinam v predelu Kulešvor, lokalni odbor za samopomoč in podobno v KHP; odbor za izboljšnje stanovanjskih območij v GLP) pa zaradi pomanjkanja sredstev, slabih upravljavskih sposobnosti, slabega sodelovanja stanovalcev ter nezadostne podpore matičnih in vladnih organizacij ne zmorejo prevzeti vloge tradicionalnih ustanov, zagotoviti družbene podpore niti oblikovati družabnega omrežja. V SHR deluje lokalni odbor, ki se bolj kot z oblikovanjem socialnih mrež ukvarja z zadevami, povezanimi $z$ vzdrževanjem stavb in infrastrukture.

$\mathrm{Z}$ anketo se je pokazalo, da skoraj tri četrtine vprašanih $\mathrm{v}$ GLP in polovica anketirancev v preostalih soseskah občasno sodeluje v programih, ki jih organizirajo lokalni okrajni urad in druge socialne ustanove (preglednica 5). Približno tretjina stanovalcev KHP in SRH pogosto obiskuje okrajni urad, predvsem zaradi osebnih zadev. V vseh soseskah je večina tovrstnih dejavnosti povezana s športom, čǐščnjem soseske ter praznovanjem novega leta in praznika luči (nep. divali).

\subsubsection{Možnosti druženja}

Javne stavbe, rekreacijski centri in socialne ustanove, kot so šole, zdravstveni domovi in vrtci, so prostori, $\mathrm{v}$ katerih se stanovalci lahko družijo. Dobro oblikovane ulice in odprti prostori lahko močno povečajo raven druženja, saj združujejo vsakodnevne »nujne dejavnosti (odhod v šolo in na delo, nakupovanje, čakanje na avtobus ali določene osebe), »neobvezne dejavnosti« (sprehajanje na svežem zraku, postavanje in uživanje $\mathrm{v}$ življenju, sedenje in sončenje) in »družabne dejavnosti « (otroška igra, pozdravi in pogovori, pasivni stiki; Gehl, 1987). Poleg tega spodbujajo stike med različnimi starostnimi skupinami tudi pomembni verski kraji, kot so templji in samostani, ter družabni in kulturni dogodki. Pomanjkanje parkov in športnih centrov, nevljudnost (metanje odpadkov na ulice in javne prostore) in propadajoče stavbe vplivajo negativno na zdravje prebivalcev (Cohen idr., 2000). 
Preglednica 5: Pogostnost javnega sodelovanja v dejavnostih, ki jih izvaja skupnost ali okrajni urad

\begin{tabular}{lllll}
\hline Soseska & \multicolumn{4}{l}{ Pogostnost sodelovanja skupnosti } \\
\hline & pogosto (\%) & običajno (\%) & občasno (\%) & opombe \\
\hline KHP & 38,9 & 11,1 & 50 & povezano s športom \\
\hline GLP & 10,5 & 15,7 & 73,8 & povezano s čiščenjem lokalne ulice \\
\hline SRH & 33,3 & 16,7 & 50 & povezano z vzdrževanjem stavb in infrastrukture \\
\hline MST & 18,2 & 31,8 & 50 & povezano s čiščenjem dvorišč in pešpoti, športom \\
\hline
\end{tabular}

Zaradi številnih razlogov obstaja v preučevanih soseskah zelo malo priložnosti za druženje. Prvič, v KHP in GLP razen nekaj odstotkov zemlje, dodeljene za javne prostore, ni na voljo javnih objektov, rekreacijskih centrov niti socialnih ustanov, kot so šole in zdravstveni domovi, zaradi česar se tovrstne storitve običajno nenačrtovano ponujajo kar v stanovanjskih stavbah. Namesto da bi bilo oblikovano okolje, ki bi podpiralo druženje, taka praksa povzroča nove težave, kot so pomanjkanje parkirnih prostorov, potresna ranljivost in kaotična ulična podoba. V SRH na primer samo ena visoka stavba, $\mathrm{v}$ kateri je trgovina $\mathrm{z}$ živili in $\mathrm{v}$ kateri potekajo tudi druge dejavnosti, zaradi omejenih funkcij in storitev nudi le malo priložnosti za druženje stanovalcev. V MST je medsebojna bližina trgovin, šol, javnih stavb (templji in samostani) in hiš omogočila živahnost in vitalnost soseske ter povečala stike med ljudmi. V zadnjem času pa se je položaj poslabšal zaradi postopnega propadanja javnih stavb, gostišč, kamnitih pitnikov in vodnjakov ter poseganja $\mathrm{v}$ javne prostore $\mathrm{v}$ templjih, na dvoriščih in trgih. $\mathrm{V}$ nobeni soseski niso na voljo vrtci, storitve podaljšanega bivanja, centri za pomoč družinam in podobne storitve, ki so danes v sodobnem svetu že nuja.

Drugič, slabo opredeljeni poljavni in polzasebni prostori na območjih prehoda med javno ulico in zasebnimi stavbami ter pomanjkanje ustreznega prostora med posameznimi stavbami in ulico zaradi poljubne usmerjenosti hiš, visokih zidov na robu parcel in razlik v tem, kako daleč od ulice so postavljene stavbe, so povzročili pojav mrtvih prostorov. To onemogoča stike med sosedi in individualne dejavnosti ter $s$ tem tudi druženje in medsebojno pomoč. Podoben je tudi položaj v SRH, kjer so posamezna stanovanja neposredno povezana $\mathrm{z}$ ulico brez zasebnih prostorov, na katerih bi se lahko razvili medsosedski odnosi.
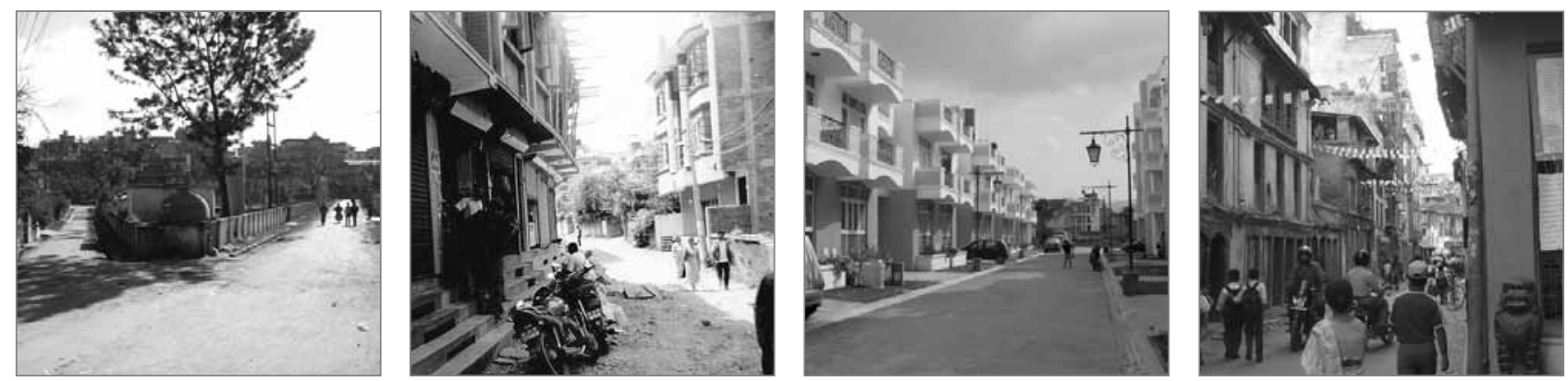

Ker fizična ograjenost homogene skupnosti zaradi povečane interakcije in zasebnosti pospešuje oblikovanje prijateljskih vezi in skupin (Festinger idr., 1950; Wells, 1965), številna stanovanjska dvorišča, ulični trgi in samostani ter kratke ozke uličice in pešpoti v MST nudijo edinstveno okolje za druženje ljudi. Zaradi komercializacije prostorov, preureditve pritličij, sprememb v strukturi stanovalcev stavb in rušenja tradicionalnih stavb sta se oslabila družbena interakcija in izvajanje skupnih dejavnosti, saj so bili večfunkcijski javni prostori spremenjeni $\mathrm{v}$ prostore s samo eno poslovno funkcijo.

Tretjič, čeprav ulice in javni prostori nudijo edinstveno okolje za druženje stanovalcev, imajo v načrtovanih soseskah le malo možnosti, da bi stanovalce pritegnili k sodelovanju v različnih dejavnostih. Ljudje teh prostorov ne uporabljajo zaradi njihove oddaljenosti od območja dnevnega gibanja pešcev, slabe prehodnosti in preglednosti ulic, prav tako ne zaradi pomanjkanja občutka ograjenosti, osnovnih javnih dobrin (klopi, ulične svetilke, drevesa in druga vegetacija) ter zaščite pred soncem in dežjem (slika 8). Posledično se trikoten odprti prostor v KHP uporablja kot odbojkarsko igrišče in vodni zbiralnik, medtem ko se manjša razdrobljena območja večinoma uporabljajo za parkirišča ter odlaganje gradbenih in gospodinjskih odpadkov. Javni prostori v GLP imajo podobno usodo.

Ureditev ulic in zasnova stavb skupaj vplivata na vzorec druženja ljudi in vrsto trgovske dejavnosti v skupnosti. Skupna dvorišča, ograje in okna hiš, ki so obrnjene druga proti drugi oziroma stojijo druga zraven druge, nudijo dodatne možnosti za druženje ter brišejo mejo med javnimi in zasebnimi prostori. V KHP in GLP takih oblikovalskih elementov ni.

Slika 8: Primerjava preučevanih sosesk z vidika druženja na ulicah (foto: Bijaya K. Shrestha) 
V anketi je večina vprašanih v KHP (57,1 \%) in MST (50 \%) odgovorila, da v svoji soseski ne najde primernega kraja ali objekta, na katerem bi lahko stanovalci navezovali prijateljske stike z drugimi člani skupnosti (slika 9). Ostali anketiranci srečujejo svoje sosede $\mathrm{v}$ družbenih stavbah (prostorih različnih organizacij skupnosti stanovalcev ali v okrajnem uradu; $28,6 \%$ vprašanih v KHP in $30 \%$ vprašanih v MST) ali na ulici in v javnih prostorih (14,3\% vprašanih v KHP in $20 \%$ vprašanih v MST). Skoraj tretjina anketirancev v GLP obiskuje družbene stavbe (na primer javni bazen), druga tretjina se $s$ sosedi pogovarja na ulicah in javnih prostorih, preostali pa se sploh ne družijo. Samo v SRH več kot polovica anketirancev hodi v nakupovalna središča, da se tam druži s sosedi. V vseh soseskah pa naštete oblike druženja niso pogoste: manj kot tretjina prebivalcev KHP in MST se s sosedi večinoma srečuje in pogovarja na ulici pri odhodu na delo, medtem ko se v GLP in SRH samo četrtina prebivalcev dnevno srečuje s svojimi sosedi. V SRH se $50 \%$ anketirancev tedensko druži s sosedi (večinoma ob vikendih, in sicer v trgovini z živili ali zunaj na ulici). Večina teh stikov je bežnih in se le redko razvije $\mathrm{v}$ pravo prijateljstvo, pri katerem lahko ljudje delijo svoje občutke in poiščejo pomoč, kadar jo potrebujejo. Nobena soseska nima ustreznega otroškega igrišča, na kar je opozorila tudi večina anketirancev.

\subsection{Kulturni vidik sosesk}

Kulturni vidik sosesk povezuje stanovanjsko skupnost $s$ fizičnim grajenim okoljem tako, da se lahko vsak stanovalec soseske čustveno naveže na urbano okolje, razume druge člane skupnosti in razvije občutek pripadnosti soseski. Kultura je sistem podedovanih pojmovanj, ki se izražajo v simbolnih oblikah, $s$ katerimi se ljudje sporazumevajo ter vzdržujejo in razvijajo svoje znanje in odnose do življenja; je neotipljiva ter se lahko opredeli z vidika skupnih pomenov in pojmovnih svetov.

\subsubsection{Občutek pripadnosti kraju in skupnosti}

Občutek pripadnosti kraju se nanaša na pripadnost določenemu okolju oziroma soseski. Posebnosti, kot so obstoječi naravni elementi ali umetni objekti, in skupno doživljanje vsakdana so pomembni vidiki, ki skupnost določene soseske ločijo od drugih skupnosti, ki niso tako povezane z določenim krajem (Hargreaves, 2004). Sčasoma postanejo posebnosti kraja pomembne za domačine, ki tam živijo, na podlagi česar se razvijejo medosebni odnosi in zavedanje o lokalnem okolju (Norberg-Schulz, 1980; Heidegger, 1993). Posameznikovega odnosa do okolja pa ne moremo obravnavati ločeno od zgodovinskih okoliščin in izkušenj z določenim krajem, ki jih posameznik sčasoma zbere (Wheeler, 1995). Materialni in nesnovni elementi ustvarijo enkratno človeško izkušnjo, ki se je lahko spominjamo, jo delimo in sporočamo, tako da na koncu postane družbena izkušnja.

Nobena od preučevanih sosesk ne priznava tega dejstva pri načrtovalskem in oblikovalskem procesu. Pri ureditvi ulic in usmerjenosti urbanih blokov v KHP načrtovalci niso izkoristili višje lege območja in obdajajočih gora, da bi prebivalcem omogočili občutek, da živijo sredi narave. V GLP se območja, kot so Gongabu, reka Samakhuši in okoliške gore, ne upoštevajo v načrtovalskem procesu, v soseski SRH pa ureditev in oblika stanovanjskih stavb ne upoštevata lokalnih naravnih elementov, kot sta reka Manohara in razgled na gore. Nove visoke stavbe prevladujejo nad templji in samostani ter zakrivajo razgled na mnoga pomembna območja in pomembne objekte, kar zmanjšuje družbeni vpliv tovrstnih objektov.

Dobro urejen kraj si lahko zlahka predstavljamo v glavi, njegovo prostorsko ureditev pa si lahko dobro zapomnimo. V tem pogledu niso pomembni samo osrednji objekti, ampak tudi pregledno speljane poti, ki vodijo do njih. Dobre soseske bi

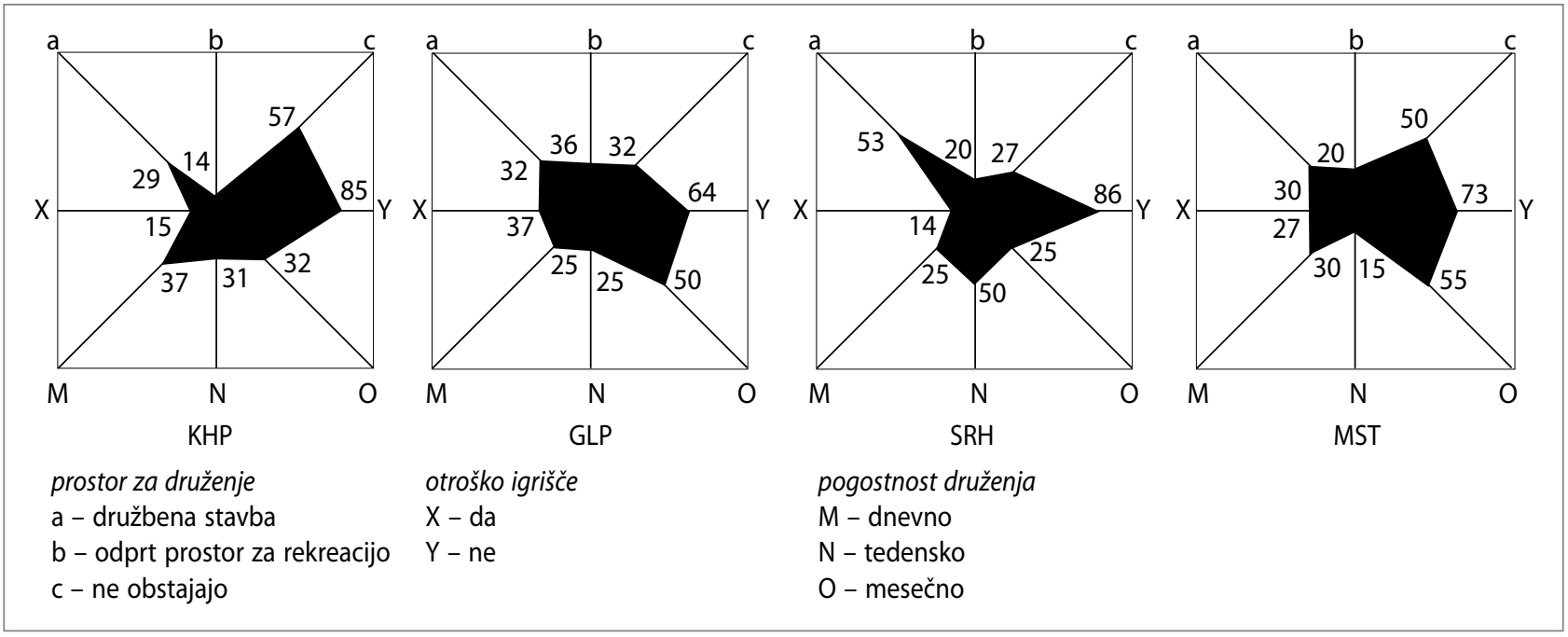

Slika 9: Primerjava odgovorov anketirancev glede krajev druženja, pogostnosti druženja in razpoložljivosti otroških igrišč 
zato morale imeti dobro prepoznavno okolje s svojo identiteto, zgradbo in pomenom, vsebovati pa bi morale tudi globino in pomembne zgodovinske plasti, ki omogočajo prepoznavanje, razumevanje in praznovanje minevanja časa (Lynch, 1972). Za stanovanjsko okolje KHP in GLP so značilni redki dostopi, dolgi in nepovezani urbani bloki brez vmesnih prečnih prehodov ter nepregledne ulice brez referenčnih točk in pomembnih objektov. V SRH dolgi in ozki urbani bloki z enakimi stavbami, ki so povezane s slepimi ulicami brez parkirišč, prav tako ne oblikujejo prepoznavnega okolja. Ker nestanovalcem vstop v to naselje ni dovoljen, domačini običajno niti ne pomislijo na to sosesko. Spreminjanje barve rož in listov na drevesih na ulicah, praznovanje lokalnih praznikov, dogodki na javnih prostorih okrog verskih objektov in podobne dejavnosti spremljajo dnevno življenje ljudi, obenem pa nakazujejo tudi spreminjanje letnih časov. Vendar te soseske ne omogočajo občutka minevanja časa. Ljudje, ki se odločijo za nakup hiše v SRH, morajo biti pripravljeni sprejeti tamkajšnji življenjski slog, saj spreminjanje zunanjosti hiš ni dovoljeno. Vse naštete značilnosti so povzročile, da ljudje ne čutijo povezanosti s svojimi kraji. Če med ljudmi ni gibanja, sporazumevanja in druženja, pravzaprav ni mogoče ustvariti občutka pripadnosti skupnosti niti kraju. V teh stanovanjskih soseskah so družbeni stroški gradnje zelo visoki, kakovost življenja pa je nizka.

Tradicionalna soseska MST ima prepoznavno urbano obliko (jasno urejeno hierarhijo ulic in javnih prostorov $s$ prepoznavnimi središci in pomembnimi objekti), bogate zgodovinske vire in kulturne vrednote, ki dajejo smisel, red in ravnotežje človeškemu obstoju (Lowenthal, 1975). Številne dejavnosti, povezane $s$ praznovanjem različnih praznikov in $\mathrm{z}$ izvajanjem verskih obredov na javnih prostorih in v stavbah, zagotavljajo prijetno okolje, ki se močno razlikuje od vsakodnevnega stanovanjskega okolja. Praznik v čast belega boga Maččhindranatha $s$ procesijo $\mathrm{z}$ vozom ter čaščenje otroške boginje Kumari na trgu Lagana in območju Džajši Devala dodatno bogatita kulturni pomen kraja. V MST pa se je zaradi zanemarjanja javnih objektov, slabenja verskih prepričanj in vdora javnih prostorov začel občutek pripadnosti kraju slabšati.

\subsubsection{Družbeni viri, vsakdanje življenje in družbeno-kulturne dejavnosti}

Viri, kot so storitve in javne dobrine, lahko pomagajo ohranjati občutek pripadnosti kraju, če so umeščeni v prostor tako, da podpirajo večje družbeno povezovanje. Poleg tega bi morala skupnost v soseski imeti možnost, da v varnem okolju opravlja svoje vsakdanje dejavnosti in sodeluje pri družbeno-verskih dejavnostih.

Ker skupna zemljǐ̌ča in viri (na primer osnovna šola, zdravstveni dom, rekreacijski in kulturni centri, parki, vrtovi in podobni javni elementi) v preučevanih stanovanjskih soseskah niso zagotovljeni (razen nekaj zemlje, namenjene javnim prostorom in v primeru SRH trgovini z živili), se odgovornost za skupna zemljišča in objekte ter občutek lastništva nista nikoli udejanjila. Stanovalci se ne zbirajo in med seboj ne sodelujejo za skupno dobro, zaradi česar tudi ni priložnosti za izmenjavo izkušenj. Poleg tega se v teh soseskah zaradi pomanjkanja pomembnih verskih objektov in krajev, povezanih z njimi, ne morejo izvajati številni lokalni prazniki in obredi. To med stanovalci slabi zaupanje in vero $\mathrm{v}$ kulturne dejavnosti.

$\mathrm{Z}$ anketo se je jasno pokazalo, da ljudje $\mathrm{v}$ vseh obravnavanih soseskah pogrešajo območja z mešano rabo zemljišč in javne dobrine. Velik del prebivalcev KPH (42 \%) meni, da je v njihovi soseski premalo pisarn, medtem ko je podoben odstotek ljudi v SRH prepričan, da imajo premalo izobraževalnih ustanov (slika 10). Skoraj enako število prebivalcev v GLP meni, da na njihovem območju ni dovolj trgovin. Med 20 in $24 \%$ vprašanih v vseh soseskah zagovarja mnenje, da ni dovolj ustanov za nujno pomoč, kot so policijske in gasilske postaje. Poleg tega pa jih skrbi tudi pomanjkanje trgovin, ustanov in pisarn. Prebivalci se zavedajo negativnih posledic nezadostne infrastrukture in storitev na tem območju, kar vodi v nezadovoljstvo s sosesko in z drugimi stanovalci ter posledično do neprimernega obnašanja.

To domnevo je dodatno potrdila tudi anketa, ki smo jo izvedli v posameznih soseskah. Velik delež vprašanih v KHP (61 \%) ni zadovoljen $\mathrm{z}$ vodno oskrbo, preostali anketiranci pa niso zadovoljni z ulicami in s kanalizacijo, pri čemer je odstotek obeh odgovorov približno enak. Prebivalce GLP in MST najbolj skrbijo težave z ulicami in vodno oskrbo, v SRH pa so najbolj nezadovoljni s tem, da nimajo telefonske povezave. Neredna in nezadostna oskrba z vodo je velik problem v vseh soseskah razen v SRH. V KHP in GLP se prebivalci pritožujejo nad neustreznim vzdrževanjem ulic, odlaganjem odpadkov na ulice in pomanjkanjem pešpoti, medtem ko se ljudje v SRH pritožujejo nad tem, da na njihovih ulicah ni dreves niti drugega rastlinja. Ker imata soseski KHP in GLP samo nekaj osamljenih trgovin, ki ponujajo najnujnejše vsakdanje potrebščine, morajo stanovalci nakupovati na sosednjih območjih; prebivalci KHP hodijo v Kalimati, Kalanki in Kulešvor, prebivalci GLP pa v predele Thamel, Gongabu Čovk in Šamakhuši. V razmerah, v katerih se večina prebivalcev še vedno spopada s težavami, povezanimi z najosnovnejšimi življenjskimi potrebami, kot so nezadostna oskrba $\mathrm{z}$ vodo, slaba kanalizacija in propadajoče ulice, druženje med sosedi ter izmenjava izkušenj, prepričanj in vrednot nista preveč pomembna.

Varnost stanovalcev in njihovega premoženja je v soseskah izredno pomembna. Dosežemo jo lahko z mešano rabo zemljišč, ustrezno ureditvijo stavb in ulic, s policijskim nadzorom, z 


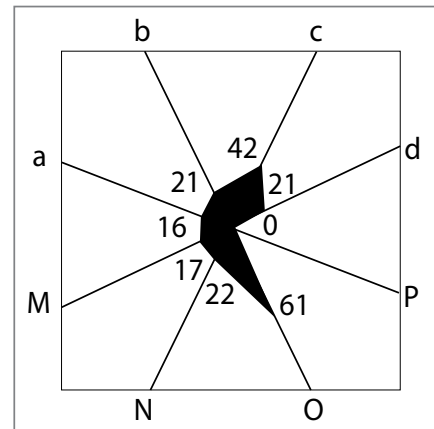

KHP

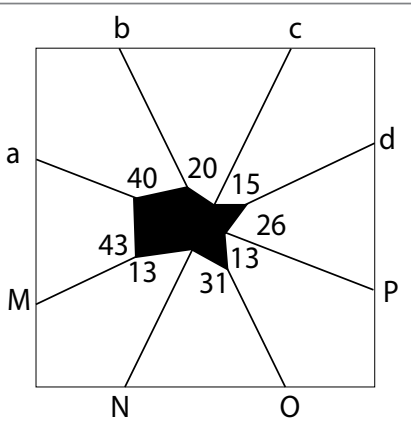

GLP

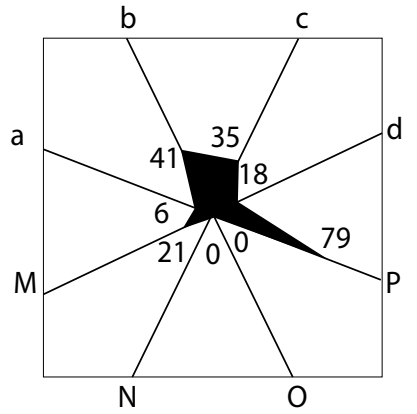

$\mathrm{SRH}$

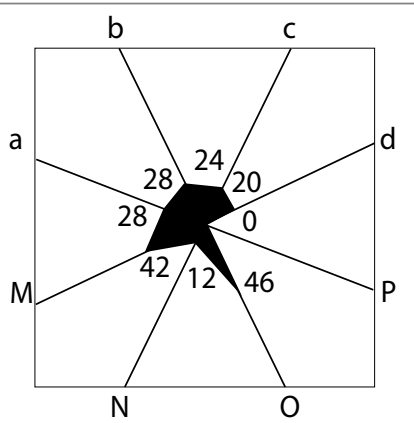

MST

manjkajoča raba zemljišč

a - trgovski objekti b-ustanove

c-pisarne $\quad d$-drugo (policija, gasilska postaja itd.)

manjkajoča infrastruktura

$\mathrm{M}$ - ulice in pešpoti $\quad \mathrm{N}$ - kanalizacija

O - oskrba z vodo $\quad \mathrm{P}$ - drugo (telefonska napeljava itd.)

Slika 10: Primerjava odgovorov anketirancev glede nezadostne rabe zemljišč in kakovosti fizične infrastrukture

varstvom pred požari, osvetljavo, dobro vidljivostjo, ustreznim vzdrževanjem pokrajine in upoštevanjem pojmov »oči na ulicah $\ll$ (ang. eyes on the streets, Jacobs, 1961) in »branljivih prostorov « (ang. defensible spaces, Newman, 1972). Tako KHP kot GLP sta daleč od tega, da bi izpolnjevali ta merila. Številni dejavniki, kot so enolična raba zemljišč, ulice brez pločnikov in prepoznavnih središč, ki so z vrati ali zidovi ločene od hiš, in pomanjkanje družbenih stavb, so prispevali $\mathrm{k}$ močnemu občutku nevarnosti. Zaradi temnih ulic, praznih parkirišč in skupin mladih moških, ki postavajo na uličnih vogalih, se ženske redkeje zadržujejo na ulicah, še zlasti ponoči. V varovanem naselju SRH nestanovalci niso zaželeni. Tradicionalne soseske, kot so MST, nudijo edinstveno varno okolje. Ograjena dvorišča in kratke, ozke ulice, na katerih potekajo različne dejavnosti, izpolnjujejo merili »oči na ulicah« ter »teritorialnosti in nadzora « (ang. territoriality and surveillance), ki povečujeta varnost. Poleg tega ženske na polzasebnih prostorih dvorišč ne vzdržujejo samo medsosedskih in družinskih vezi, ampak pomagajo tudi oblikovati, določati in nadzorovati meje soseske.

$\mathrm{Z}$ anketo se je jasno pokazalo, da se sicer večina ljudi (razen v GLP) v svojih soseskah počuti varna, vendar se kljub temu pojavljajo primeri družbenega kriminala. Anketiranci v KHP, ki se v svoji soseski ne počutijo varne, kot največji družbeni problem navajajo tatvine (preglednica 6). Prebivalce MST pa skrbijo tatvine, vandalizem in zloraba drog. Samo v SRH stanovalci do zdaj v svoji soseski niso bili priča kakršnemu koli pojavu družbenega kriminala. Rezultati ankete in kazenska evidenca vsega okraja kažeta, da je GLP najnevarnejša soseska. Večina stanovalcev (74 \%) navaja, da so v njihovi soseski največji družbeni problemi tatvine, vandalizem, zloraba drog in prostitucija. Več kot 70 \% stanovalcev vseh sosesk (68,1\% v MST) se običajno vrača domov pred 20. uro. Slabe varnostne razmere in dejstvo, da se ponoči pravzaprav nič ne dogaja, so med stanovalci vseh sosesk še okrepile občutek, da živijo v nevarnem okolju.

Razen v soseski SRH si več kot polovica stanovalcev iz drugih sosesk želi imeti otroško igrišče, manj kot petina pa meni, da v soseski potrebujejo več trgovin (slika 11). Približno četrtina anketirancev v vsaki soseski meni, da potrebujejo športni center. Večina stanovalcev v SRH si želi, da bi v njihovi soseski zgradili več družbenih stavb, saj imajo trenutno samo trgovino z živili. $V$ drugih soseskah pa gradnjo družbenih stavb podpira približno $10 \%$ anketirancev.

Elemente, ki med stanovalci veljajo za priljubljene ali nepriljubljene, lahko razdelimo $\mathrm{v}$ štiri skupine (slika 12): (a) sosedje, (b) domače okolje, (c) fizična infrastruktura in (d) kulturne dejavnosti. Med stanovalci KHP so najbolj priljubljeni sosedje (36,3\% - prijazni in pripravljeni pomagati), sledijo jim domače okolje $(27,3 \%$ - višja lega, zeleni pas z odprtimi prostori in podobno), fizična infrastruktura $(21,2 \%$ - načrtno zgrajeno območje, avtomobilski dostop do vsake parcele in

Preglednica 6: Primerjava mnenj stanovalcev glede občutka varnosti in kriminala v soseskah

\begin{tabular}{|c|c|c|c|c|c|c|c|}
\hline \multirow[t]{2}{*}{ Soseska } & \multicolumn{2}{|c|}{ Varnost (\%) } & \multicolumn{3}{|c|}{ Vrsta družbenega kriminala (\%) } & \multicolumn{2}{|c|}{ Čas vračanja domov (\%) } \\
\hline & $\mathrm{da}$ & ne & tatvine & vandalizem & droge/prostitucija & pred 20. uro & po 20. uri \\
\hline KHP & 81 & 19 & $100\left(36^{*}\right)$ & 0 & $0\left(22^{*}\right)$ & 83,4 & 16,6 \\
\hline GLP & 26,3 & 73,7 & $44,4\left(15^{*}\right)$ & 27,7 & $27,9\left(150^{*}+50^{* *}\right)$ & 70,5 & 29,5 \\
\hline $\mathrm{SRH}$ & 92,8 & 7,2 & 0 & 0 & 0 & 75 & 25 \\
\hline MST & 86,3 & 13,7 & 57,1 & 28,5 & 14,4 & 68,1 & 31,9 \\
\hline
\end{tabular}

Opomba: $\left(^{*}\right)$ število primerov zlorabe drog v vsem okraju; $\left(^{* *}\right)$ število primerov prostitucije v vsem okraju 


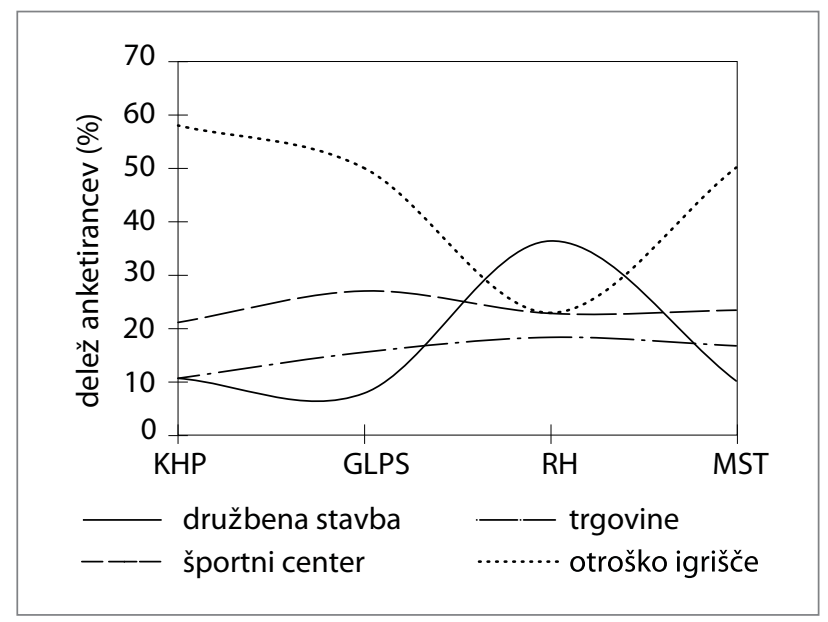

Slika 11: Zaželeni storitveni objekti

podobno) in kulturne dejavnosti $(15,2 \%$ - druženje in praznovanje praznikov). Veliko ljudi se je pritoževalo nad fizično infrastrukturo (53,6 \% - slaba oskrba z vodo in kanalizacija, propadajoče ulice, visoka gostota gradnje, nimajo športnega centra in podobno), domačim okoljem ( $25 \%$ - slaba uporaba odprtih prostorov, nimajo otroškega igrišča, na ulicah ni zelenih nasadov in podobno) in sosedi (21,4 \% - egoistični, niso pripravljeni sodelovati $z$ drugimi, motijo druge in podobno). V GLP so ljudje najbolj zadovoljni s fizično infrastrukturo ( $46,3 \%$ - bazen, dobro prevozne ulice in podobno), $z$ domačim okoljem ( $23 \%$ - mirno, odprti prostori, nekaj čudovitih domov in podobno) in s sosedi ( $23 \%$ - pripravljeni sodelovati in pomagati, prijazni, razumevajoči in podobno). Hkrati sta ta elementa tudi vir največjega nezadovoljstva med ljudmi: fizične infrastrukture ne mara 52,2\% stanovalcev (slabe in ozke ulice brez zelenih nasadov in ustreznih odprtih prostorov, slaba električna in vodna oskrba ter podobno), sosedov pa 30,4 \% (sebični, prepirljivi, motijo druge, odlagajo odpadke na ulico in javne prostore in podobno). V SRH je fizična infrastruktura hkrati najbolj in najmanj priljubljen element soseske (deleža odgovorov znašata $76,6 \%$ in 50 \%). Skoraj $42 \%$ stanovalcev ne mara domačega okolja, $17 \%$ pa jih ne mara svojih sosedov. Razlogi za nepriljubljenost domačega okolja so monotonost, dolgočasje in omrtvelost, poleg tega primanjkuje družbenih stavb ter zelenih nasadov in parkov. Samo v MST so najbolj priljubljeni element kulturne dejavnosti (68,4\% - templji bodisatve Mandžušrija, samostani, lokalni prazniki, tradicionalne spretnosti in tradicionalne stavbe).V drugih treh soseskah med priljubljenimi elementi kraja le malo ljudi omenja kulturne dejavnosti. Soseska v središcu mesta (MST) se spopada s slabo infrastrukturo (57,2\% - propadajoče ulice, visoke stavbe, puščanje kanalizacije in podobno), ljudje pa so nezadovoljeni tudi $s$ sosedi $(26,5 \%$ - nočejo sodelovati, spopadi med tolpami, negativen odnos do najemnikov in podobno).

\section{Slabosti preučevanih sosesk}

\subsection{Neustrezno in neučinkovito prostorsko načrtovanje, gradnja in prenova}

$\mathrm{Na}$ vseh treh načrtno zgrajenih območjih je bila pri prostorski ureditvi ulic, urbanih blokov in parcel upoštevana načrtovana raba posameznih parcel (v GLD dejstvo, da se bodo vrnile

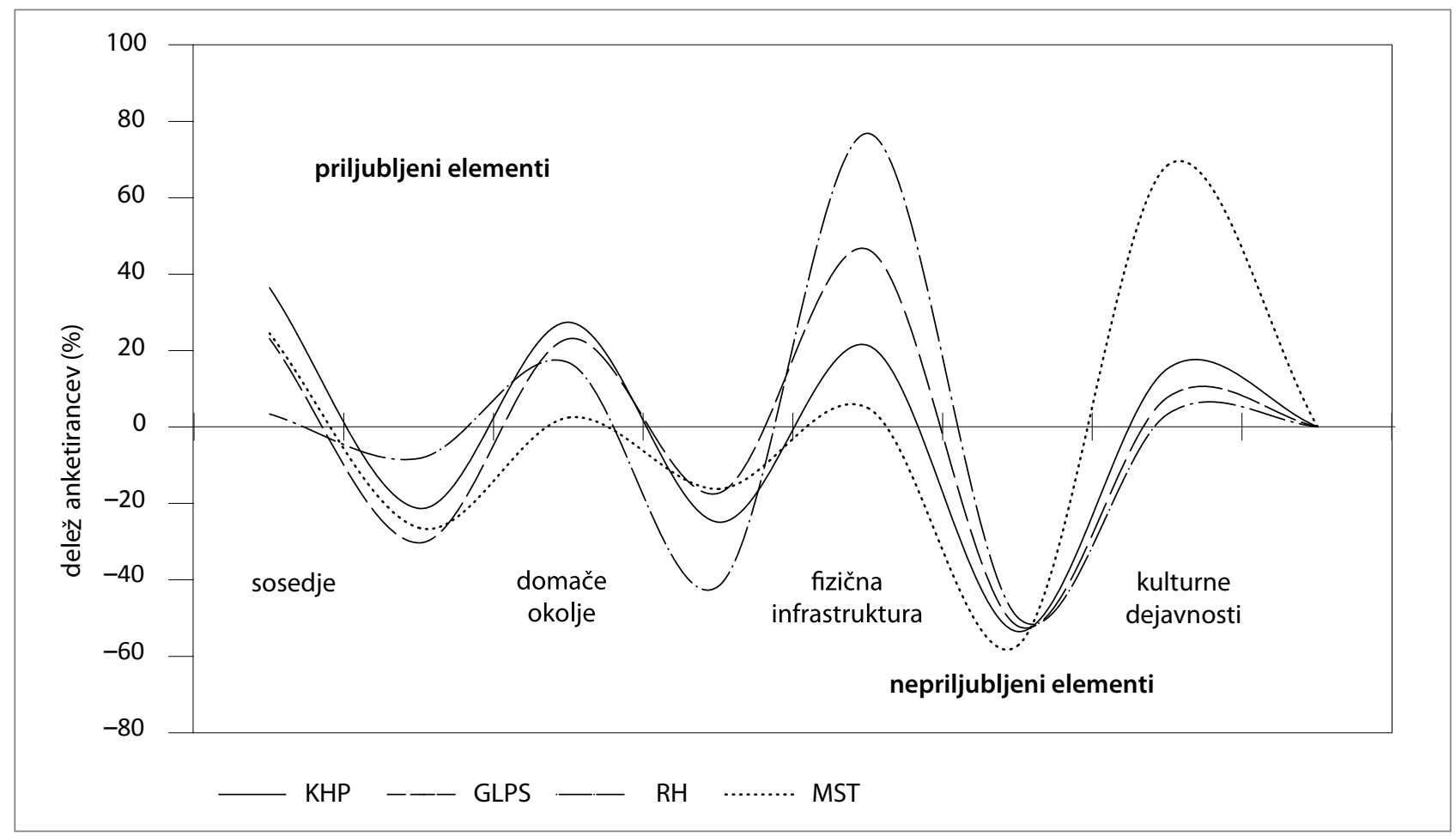

Slika 12: Najbolj in najmanj priljubljeni elementi sosesk 
lastnikom, in v KHP dejstvo, da so se oblikovale standardne parcele), $s$ čimer so želeli oblikovati čim večje število komunalno opremljenih parcel. Po parcelaciji zemljišč in razmejitvi uličnega omrežja je vsak lastnik posameznega zemljišča zgradil hišo in njeno rabo opredelil $\mathrm{v}$ skladu $\mathrm{z}$ veljavnimi gradbenimi predpisi. ${ }^{[11]} S$ tem se je končal proces načrtovanja. Pri projektu gradnje zasebnih stanovanj v SRH pa lahko na podlagi ureditve grajenega okolja sklepamo, da je bila glavna želja načrtovalcev ustvariti čim večji dobiček in ne zadovoljiti potreb stanovalcev. Ta naselja ne izpolnjujejo niti najosnovnejših meril sosesk, kot sta osnovna šola in zdravstveni dom na razdalji, ki jo lahko stanovalci prehodijo peš. Pri njihovem načrtovanju se ni upoštevalo, da je treba določiti posebnosti območja in preučiti, kako se to povezuje z okolico, prav tako ni bila določena hierarhija med seboj povezanih kratkih ulic in javnih prostorov ter nepretrganosti arhitekturnega pomena, da bi se oblikovalo prepoznavno urbano okolje ter prostori za druženje in rekreacijo in da bi se ustvaril občutek pripadnosti skupnosti. $S$ tovrstnim kratkovidnim osredotočanjem na posamezno parcelo in gradnjo na njej ne moremo nikoli ustvariti zdravega bivalnega okolja. Proces urbane preobrazbe v MST - zamenjava tradicionalnih stavb z novimi stolpnicami, ki se ne skladajo $\mathrm{z}$ okoljem, spremembe $\mathrm{v}$ strukturi stanovalcev stavb in rabi zemljiščc, ki jih določa trg, ter vdor prometa na javne prostore in ulice - ne more ohranjati tradicionalne narave tega dela mesta niti ne more izpolnjevati sodobnih potreb prebivalcev. Posledica tega je vztrajno uničevanje edinstvenega tradicionalnega okolja MST.

\subsection{Slabe priložnosti za druženje}

Določitev zemljišč za gradnjo stanovanj brez ureditve socialnih, lokalnih in intervencijskih objektov, slabo prostorsko načrtovanje ter posledična slaba ureditev omrežja ulic in javnih prostorov, gradnja izoliranih stavb brez ustreznih prostorov med hišami ter med ulico in posamezno hišo in nesposobnost družbenih ustanov, da razširijo socialno mrežo, so zmanjšali možnosti navezovanja stikov in druženja med stanovalci na teh načrtno zgrajenih območjih, sčimer so med njimi oslabili medsebojno pomoč ter občutek pripadnosti kraju in skupnosti. Poleg tega so se v MST zaradi večje gostote prebivalcev in vozil (zaradi česar stare stavbe zamenjujejo trgovska poslopja), vdora poslovnih dejavnosti v javne prostore in samovoljnega preoblikovanja vzorcev gradnje stavb zmanjšale priložnosti za druženje, obenem pa je to oslabilo prejšnji družbeni sistem in kulturno prakso, ki sta to sosesko vzdrževala več generacij. $\mathrm{Z}$ vidika druženja so te načrtovane soseske manj prijazne od stanovanjskih naselij, ki nastajajo spontano. ${ }^{[12]}$

\subsection{Oslabljen občutek pripadnosti kraju in skupnosti}

V vseh preučevanih soseskah so neugodna lokacija in slabe možnosti za druženje ljudi ločile od njihovih krajev, zaradi česar je oslabela njihova povezanost z grajenim okoljem in drugimi člani skupnosti. Prebivalci teh sosesk imajo v vsakdanjem življenju še vedno težave z nezadostno vodno oskrbo, s slabo kanalizacijo ter slabo vzdrževanimi ulicami in javnimi prostori. Poleg tega zaradi pomanjkanja verskih objektov le težko izvajajo dnevne obrede in družbeno-kulturne dejavnosti. Vse to prispeva k oslabljenemu občutku pripadnosti kraju in skupnosti.

\subsection{Neprimerni in neučinkoviti pravni in institucionalni okviri}

Trenutno se z nobenim zakonom ne usmerja načrtovanje in oblikovanje novih stanovanjskih sosesk niti obnova starih sosesk. Zakon o lastništvu skupnih stanovanj 2054 iz leta 1997 (uradni list Republike Nepal z dne 15. aprila 2003) se bolj osredotoča na dovoljenja za gradnjo stanovanj, njihovo prodajo in prenos lastništva kot na urejanje glavnega načrta, razvoj infrastrukture in gradnjo posameznih stavb. Edini pravni aparat, ki nadzoruje tovrstno gradnjo, so veljavni gradbeni predpisi. Zato se določitev rabe zemljišč, ureditev javnih prostorov in ulic, gradnja javnih objektov in razvoj infrastrukture razlikujejo od projekta do projekta.

Petim kategorijam vladnih ustanov, ki so odgovorne za načrtovanje rabe zemljišč in razvoj mest, ni uspelo pripraviti glavnega načrta, ki bi določal mešano rabo zemljišč na posameznem območju, poleg tega pa tudi zelo slabo nadzorujejo gradnjo posameznih stavb in infrastrukture. Prav tako jim ne uspe preprečiti uničevanja tradicionalne soseske MST. S tem se izgublja priložnost za načrtovanje novih stanovanjskih območij z mešano rabo zemljišč ter družbenih in intervencijskih objektov, kot tudi za nadzorovanje gradnje posameznih stavb in infrastrukture, pri čemer bi se preventivni elementi vključili $\mathrm{v}$ glavne načrte in oblikovanje stavb, kar bi zagotovilo varne in zdrave soseske.

\section{Sklep}

Če upoštevamo uporabljeni analitični okvir ter kvalitativno in kvantitativno analizo, ki smo ju izvedli, lahko ugotovimo, da preučevane stanovanjske soseske v Katmanduju niso zgodba o uspehu. Njihovi prebivalci dejansko nimajo občutka, da pripadajo kraju in imajo dom. Gre za okolje z velikim številom zasebnih celic, $v$ katerih družinski člani skupaj obedujejo, spijo ter se $\mathrm{v}$ določeni meri družijo $s$ sorodniki in prijatelji. Ta 
načrtovana naselja kažejo marsikaj. Prvič, razen soseske MST so zelo dober primer tega, kako se v prihodnosti stanovanjske soseske resnično ne smejo graditi . Drugič, potrjujejo neprimernost in neučinkovitost obstoječih pravnih predpisov ter nesposobnost institucij na področju načrtovanja, gradnje in upravljanja stanovanjskih območij. Tretjič, simbolizirajo izgubljeno priložnost za gradnjo varnih in živahnih stanovanjskih sosesk, ki nadaljuje preteklo prakso in obenem izpolnjuje današnje potrebe. Četrtič, ponazarjajo primer nezmožnosti prepoznavanja edinstvenih značilnosti stare soseske v središču mesta ter njenega propadanja in uničevanja. Ne nazadnje pa potrjujejo tudi to, da se njihovi stanovalci le malo zanimajo za okolje, v katerem živijo. Ker obstoječi neprimerni in neučinkoviti pravni in institucionalni okviri ne morejo rešiti teh težav, je treba za prihodnjo gradnjo stanovanjskih sosesk razviti oblikovalske smernice in jih strogo izvajati, poleg tega pa tudi okrepiti družbeno-kulturne dejavnosti, vključno z navezovanjem stikov. Za gradnjo primernih stanovanjskih sosesk priporočamo te načrtovalske in oblikovalske smernice:

(a) Prostorski vidiki

- določitev naravnih in zgodovinskih značilnosti območja, ki imajo kolektivni pomen, ter njihovo upoštevanje pri ureditvi soseske in grajenega okolja;

- oblikovanje glavnega načrta, ki omogoča, da se ulice in javni prostori s stavbami in posameznimi detajli uredijo prepoznavno, da se dosežejo primeren obseg, velikost in raznovrstnost javnih prostorov ter zaželena gostota, raznolikost in živahnost mestnega okolja;

- zagotavljanje primernega števila kakovostnih socialnih in intervencijskih objektov na ustreznih lokacijah;

- oblikovanje posameznih stavb, ki upoštevajo tradicionalno arhitekturno prakso, podnebje ter bližnje stavbe in ulice, s tem pa dopolnjujejo stanovanjsko okolje.

(b) Družbeni vidiki

- oblikovanje lokalnih ustanov, ki krepijo socialno mrežo in družbeno podporo;

- oblikovanje jasne prostorske hierarhije (javni prostor, poljavni prostor, polzasebni prostor, zasebni prostor) z jasno določljivimi kraji, na katerih se lahko prebivalci družijo, delajo in se sprostijo. Prav tako je treba oblikovati funkcionalne prostore in prostore glede na merilo človeka za različne starostne skupine, ki se lahko uporabljajo ob različnem času in na različne načine, kar zagotavlja živahnejše in varnejše javno okolje.

(c) Kulturni vidiki

- oblikovanje prostorov ter podpiranje dejavnosti in dogodkov, pri katerih lahko prebivalci spoznavajo običaje in razvijejo skupne vrednote, kar krepi medosebne vezi in medsebojno podporo;

- zagotavljanje javnih dobrin in različnih objektov na pri- mernih lokacijah ter varnega okolja, v katerem lahko prebivalci udobno in nemoteno opravljajo svoje vsakodnevne dejavnosti, izvajajo obrede in praznujejo praznike.

Bijaya K. Shrestha

S (settlement-society-sustainability) 3 Alliance, Development Forum for Habitat, Katmandu, Nepal

E-pošta: bibiyan_shrestha@yahoo.co.uk

\section{Opombe}

${ }^{[1]}$ Izraz »enota soseske« je skoval William E. Drummond, leta 1929 pa je njegov pomen razširil Clarence Perry.

${ }^{[2]}$ Do 70 . in 80 . let 20. stoletja so zasebni investitorji gradili trgovske in pisarniške komplekse ter skupne objekte, kot so parki in sprehajališča, zaradi česar so imeli vse pomembnejšo vlogo pri oblikovanju javnih prostorov.

${ }^{[3]}$ Do te stanovanjske soseske v predelu Balkumariv na submetropolitanskem območju Lalitpurja lahko zlahka dostopamo iz številnih središč dejavnosti v Katmanduju.

${ }^{[4]} \vee$ primerjalni raziskavi trg Mandžušri pokriva približno tretjino vsega okraja, saj je $v$ središču mesta izredno težko določiti jasne meje posameznih sosesk.

${ }^{[5]}$ Domneva se, da vsako gospodinjstvo v povprečju šteje pet članov.

[6] Tistih nekaj urbanih blokov, ki so s pešpotmi razdeljeni na manjše dele, nismo upoštevali.

${ }^{[7]}$ Horacio Caminos in Reinhard Goethert (1978) sta predlagala, naj se prometu nameni vsaj 20 in največ $30 \%$ površine stanovanjske soseske, medtem ko Svetovna banka pogosto priporoča, naj se pri gradnji stanovanj prometu nameni 20-25\% površine stanovanjske soseske.

Za dostop reševalnih vozil morajo biti glavne ulice široke vsaj 10, 7 ali 5 metrov.

${ }^{[8]}$ Hipotetični model, ki sta ga razvila Martin Leslie in Lionel March (1972), je pokazal, da lahko pri dvoriščnem tipu v stavbi živi petkrat več ljudi kot pri paviljonskem tipu in 1,6-krat več ljudi kot pri vrstnem tipu.

[9] Guthiji so bili organizacije, ki so se stalno financirale s pomočjo dohodka od zemlje in so učinkovito usmerjale sredstva v javne namene.

${ }^{[10]}$ Veliko prišlekov iz različnih kast (brahmani, četri, gurung) živi tukaj zaradi dela ali ima stanovanje $v$ začasnem najemu.

[11] Za stanovanjsko sosesko Kulešvor veljajo nekatera dodatna pravila, in sicer stavbe morajo stati 2 metra stran od roba ulice in 2 metra druga od druge, tako da lahko stanovalci nemoteno odprejo svoja okna, prav tako ne smejo biti višje od 12,2 metra (4 nadstropja).

[12] Na nenačrtno grajenih območjih ustvarijo dostop (stranske ulice in ozke glavne ulice) s pomočjo sosedov, s katerimi kramljajo na terasah, oknih in pri vhodih $v$ stanovanja, do mnogih dnevno potrebnih dobrin pa lahko dostopajo peš, ne da bi prečkali prometno cesto.

\section{Viri in literatura}

Bartuska, T. J. (1994): Cities today: The imprint of human needs in urban patterns and form. V: Bartuska, T. J., in Young, G. L. (ur.): The built environment: Creative inquiry into design and planning, str. 273-288. New York, Crisp Publication.

Bentley, I., Alcock, A., Murrain, P., McGlynn, S., in Smith, G. (1985): Responsive environments: A manual for designers. London, The Architectural Press. 
Caminos, H., in Goethert, R. (1978): Urbanisation primer. Cambridge, The MIT Press.

Cohen, D., Spear, S., Scribner, R., Kissinger, P., Mason, K., in Wildgen, J. (2000): "Broken windows" and the risk of gonorrhoea. American Journal of Public Health, 90(2), str. 230-236. DOI: 10.2105/AJPH.90.2.230

Coleman, R. P. (1978): Attitudes towards neighbourhoods: How Americans choose to live. Cambridge, MA, Joint Center for Urban Studies.

Colquhoun, I., in Fauset, P. G. (1991): Housing design in practice. Harlow, Longman Scientific and Technical.

Coolen, H., in Ozaki, R. (2004): Culture, lifestyle and the meaning of a $d$ welling. Prispevek je bil predstavljen na konferenci z naslovom International Conference on Adequate and Affordable Housing for All: Research, Policy and Practice, ki je potekala od 24. do 27. junija $2004 \mathrm{v}$ Torontu v Kanadi. Tipkopis.

Davis, K. (1949) Human Society. New York, MacMillan.

Douglas, M. (1966): Purity and danger: An analysis of the concepts of pollution and taboo. London, Routledge and Kegan Paul. DOI: 10.4324/9780203361832

Downs, A. (1981): Neighbourhoods and urban development. Washington, D.C., Brookings Institution.

Duany A., in Zyberk, E. P. (1994): The neighbourhood, the district and the corridor. V: Katz, P. (ur.): The new urbanism: Toward an architecture of community, str. 17-20. New York, McGraw Hill.

Festinger, L., Schacter, S., in Back, K. (1950): Social pressures in informal groups: A study of human factors in housing. New York, Harper Bros.

Ford, L. R. (1999): Lynch revisited: New urbanism and theories of good city form. Cities, 16(4), str. 247-257. DOI: 10.1016/S0264$-2751(99) 00023-2$

Galster, G. C. (1987): Homeowners and neighbourhood reinvestment. Durham, NC, Duke University Press.

Gans, H. (1962): Urbanism and suburbanism as ways of life. V: Rose, M. (ur.) Human behaviour and social process, str. 625-648. London, Routledge and Kegan Paul.

Gehl, J. (1987): Life between buildings: Using public space. New York, Van Nostrand Reinhold.

Greetz, C. (1973): The interpretation of cultures: Selected essays. New York, Basic Books.

Hall, E. T. (1966): The Hidden dimension. New York, Doubleday and Company.

Hargreaves, A. (2004): Building communities of place: Habitual movement around significant places. Journal of Housing and the Built Environment, 19(49), str. 49-65. DOI: 10.1023/B:JOHO.0000017706.38123.43

Heidegger, M. (1993): Building dwelling thinking. V: Krell, F. D. (ur.): Basic writings, str. 213-265. London, Routledge.

Heng, C. K., in Chan, V. (2000): The making of successful public space: A case study of people's park square. Urban Design International, 5(1), str. 27-35. DOI: 10.1057/palgrave/udi/9000006

Ho, D. C W., Yau, Y., Law, C. K., Poon, S. W., Yip, H. K, in Liusman, E. (2012): Socialna zdržnost pri urbani prenovi: ocena želja skupnosti. Urbani izziv, 23(1), str. 49-63. DOI: 10.5379/urbani-izziv-2012-23-01-005

Jacobs, A. B. (1993): Great streets. Cambridge, MA, The MIT Press.

Jacobs, J. (1961): The death and life of great American cities. London, Cox and Wyman.

Lachman, M. L., in Downs, A. (1978): The role of neighbourhoods in the mature metropolis. V: Leven, C. L. (ur.): The mature metropolis, str. 362370. New York, Lexington Books.

Lennard, S. H. C., in Lennard, H. L. (1995): Livable cities observed: A source book of images and ideas for city officials, community leaders, architects, planners and all other committed to making their cities livable. Carmel, CA, Gondolier Press.

Lowenthal, D. (1975): Past time, present place: Landscape and memory. The Geographical Review, 65(1), str. 1-36. DOI: 10.2307/213831

Lynch, K. (1972): What time is this place. Cambridge, MA, The MIT Press. Lynch, K. (1981): A theory of good city form. Cambridge, MA, The MIT Press.

Maclver, R. M., in Page, C. (1955): Society. London, MacMillian.

Martin, L., in Lionel, M. (ur.) (1972): Urban space and structure. London, Cambridge University Press.

Metropolitansko območje Katmanduja (2001): Ward profile. Katmandu.

Newman, O. (1972): Defensible space, crime prevention through urban design. New York, MacMillian.

Norberg-Schulz, C. (1980): Genius loci: Towards a phenomenology of nature. London, Academy Editions.

Oriental Construction and Development (brez datuma). Sunrise homes: International style living - bungalows. Katmandu.

Ownership of joint housing act, 2054 (1997). Uradni list Republike Nepal z dne 15. aprila 2003. Katmandu.

Proshansky, H. M. (ur.) (1970): Environmental psychology. New York, Holt, Rinehart \& Winston.

Rapport, A. (1988): Levels of meaning in the built environment. V: Poyatos, F. (ur.): Cross cultural perspectives in nonverbal communication, str. 317-336. Toronto, Hogrefe.

Rapport, A. (1990): The meaning of the built environment. Tucson, University of Arizona Press.

Rodwin, L., in Hollister, R. M. (ur.) (1984): Cities of the mind. New York, Plenman Press.

Roseland, M. (1998): Toward sustainable communities: Resources for citizens and their government. Gabriola Islands, New Society Publishers.

Segovia, O. (1997): The woman dweller: Public space in Santiago. V: Beall, J. (ur.): A city for all: Valuing difference and working with diversity, str. 89-93. London and New Jersey, Zed Books.

Sherwin, G. (1992): Cityshape: Communicating and evaluating community design. Journal of American Planning Association, 58(2), str.177-189. DOI: 10.1080/01944369208975792

Shrestha, B. K. (2002): Reducing earthquake vulnerability in Kathmandu Metropolitan City. Development Insight. A Quarterly Development Journal of Nepal, 1(2), str. 36-41.

Shrestha, B. K. (2010): Preskrba s stanovanji v dolini Katmanduja: javne in zasebne pobude. Urbani izziv, 21(2), str. 16-26. DOI: 10.5379/urbani-izziv-2010-21-02-002

Shrestha, B. K. (2011): Tipologija ulic v Katmanduju in njihova preobrazba. Urbani izziv, 22(2), str. 34-48. DOI: 10.5379/urbani-izziv-2011-22-02-004

Tonnies, F. (1955): Gemeinschaft und Gesellschaft [Community and association]. London, Routledge and Kegan Paul.

Urad za mestni razvoj in gradnjo (2003): Land pooling (What, Why, Where and How). Katmandu, ministrstvo za prostorsko načrtovanje in delo.

Urad za stanovanja in mestni razvoj (brez datuma): Land development program: Documentation and reviews of sites and services, guided land development and land pooling projects in Nepal. Katmandu.

Von Eckardt, W. (1978): Back to the drawing board: Planning livable cities. Washington, D. C., New Republic Books.

Well, B. (1965): The psycho-social influence of building environments: Sociometric findings in large and small office spaces. Building Science, 1(2), str. 153-165. DOI: 10.1016/0007-3628(65)90016-2 
Wheeler, W. M. (1995): Elderly residential experience: The evolution of places as residence. New York, Garland.

Wirth, L. (1964): On cities and social life. Chicago, University of Chicago Press.

Yau, Y. (2011): Ali celovita sanacija vpliva na spremembo cen stanovanj? Študija primera v predelu Mongkok v Hongkongu. Urbani izziv, 22(2), str. 25-33. DOI: 10.5379/urbani-izziv-2011-22-02-003

Yau, Y. (2012): Nepomembno ali prezrto? Protisocialno vedenje $v$ zasebnih stanovanjih v Hongkongu. Urbani izziv, 23(2), str. 27-35. DOI: 10.5379/urbani-izziv-2012-23-02-003 